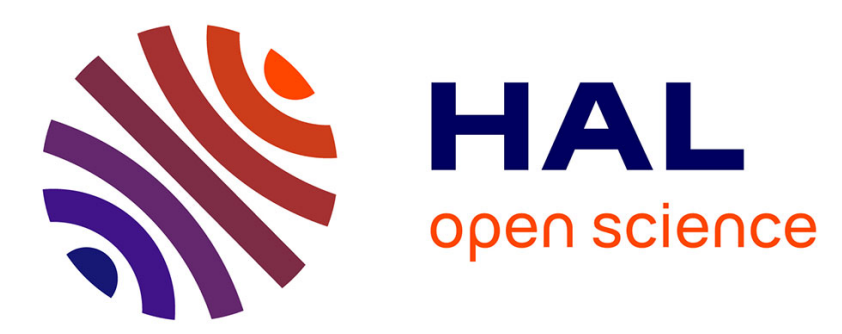

\title{
Real Estate Prices and Corporate Investment: Theory and Evidence of Heterogeneous Effects across Firms
}

Denis Fougère, Rémy Lecat, Simon Ray

\section{To cite this version:}

Denis Fougère, Rémy Lecat, Simon Ray. Real Estate Prices and Corporate Investment: Theory and Evidence of Heterogeneous Effects across Firms. Journal of Money, Credit and Banking, 2019, 51 (6), pp.1503-1546. 10.1111/jmcb.12631 . hal-02274289

\section{HAL Id: hal-02274289 \\ https://hal-amu.archives-ouvertes.fr/hal-02274289}

Submitted on 12 Mar 2020

HAL is a multi-disciplinary open access archive for the deposit and dissemination of scientific research documents, whether they are published or not. The documents may come from teaching and research institutions in France or abroad, or from public or private research centers.
L'archive ouverte pluridisciplinaire HAL, est destinée au dépôt et à la diffusion de documents scientifiques de niveau recherche, publiés ou non, émanant des établissements d'enseignement et de recherche français ou étrangers, des laboratoires publics ou privés. 


\title{
WORKING
}

paper

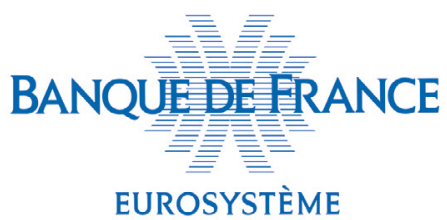

EUROSYSTÈME

\section{REAL ESTATE PRICES AND CORPORATE INVESTMENT: THEORY AND EVIDENCE OF HETEROGENEOUS EFFECTS ACROSS FIRMS}

Denis Fougère ${ }^{1}$, Rémy Lecat ${ }^{2}$, Simon Ray $^{3}$

April 2017, WP \#626

\begin{abstract}
In this paper, we investigate the effect of real estate prices on productive investment. We build a simple theoretical framework of firms' investment with credit rationing and real estate collateral. We show that real estate prices affect firms' borrowing capacities through two channels. An increase in real estate prices raises the value of the firms' pledgeable assets and mitigates the agency problem characterizing the creditor-entrepreneur relationship. It simultaneously cuts the expected profit due to the increase in the cost of inputs. While the literature only focuses on the first channel, the identification of the second channel allows for heterogeneous effects of real estate prices on investment across firms. We test our theoretical predictions using a large French database. We do find heterogeneous effects of real estate prices on productive investment depending on the position of the firms in the sectoral distributions of real estate holdings. Our preferred estimates indicate that a $10 \%$ increase in real estate prices causes a $1 \%$ decrease in the investment rate of firms in the first decile of the distribution but a $6 \%$ increase in the investment rate of firms belonging to the last decile. ${ }^{4}$
\end{abstract}

Keywords: Firms' investment, Real estate prices, Collateral channel, Financial constraints. JEL classification: D22, G30, O52, R30

\footnotetext{
${ }^{1}$ CNRS, OSC and LIEPP (Sciences Po, Paris), Banque de France, CEPR and IZA, denis.fougere@sciencespo.fr

${ }^{2}$ Banque de France, remy.lecat@banque-france.fr

3 Banque de France and Aix-Marseille University (Aix-Marseille School of Economics), CNRS, EHESS, simon.ray@banque-france.fr

${ }^{4}$ The authors would like to thank, without implicating, Philippe Aghion, Gilbert Cette, Thomas Chaney, Laurent Gobillon, Johan Hombert, Pauline Gandré, Claire Lelarge, Conor O'Toole and Jean-Marc Robin for helpful comments and suggestions. We also thank seminar participants at Aix-Marseille School of Economics, the Central Bank of Ireland workshop on "Banking, Credit and Macroprudential Policy", the Banque de France research seminar, the Royal Economic Society 2016 conference and the 2016 Annual meeting of the French Economic Association. Denis Fougère acknowledges support from the French National Research Agency's (ANR) “Investissements d'Avenir” grants ANR-11-LABX-0091 (LIEPP). Working Papers reflect the opinions of the authors and do not necessarily express the views of the Banque de France. This document is available on publications.banque-france.fr/en
} 


\section{NON-TECHNICAL SUMMARY}

In this paper, we estimate the effect of real estate prices on productive investment (i.e., machines, equipment and intangible assets), focusing on potential heterogeneous impacts depending on the composition of the firms' assets. We first formalize the link between real estate prices and productive investment in a context where credit markets are frictional thanks to a partial equilibrium model, we then bring our theoretical predictions to the data to show that an increase in local real estate prices hinders the investment of firms that do not benefit from a collateral channel.

From the late nineties to the financial crisis, real estate prices in many advanced countries have experienced a boom, unprecedented in size and duration. This has led to question the impact of this boom on productive investment. In countries where a bust has followed the boom like Spain, the adjustment revealed a significant capital misallocation and led to a rebalancing towards the exporting sector (Cette, Fernald and Mojon, 2016). On the contrary, in France, real estate prices did not correct significantly and remained higher than in the nineties relative to consumer or equipment prices. Yet, France is also subject to questioning about the impact of the real estate prices boom on sectoral allocation and on productive investment (Askenazy, 2016): did the real estate boom alter the allocation of investment towards less productive sectors or firms?

The literature has focused so far on the collateral channel that connects real estate prices to productive investment. In an imperfect credit market, collateral pledging enhances the firms' borrowing capacities. The ability of the lenders to seize pledged collateral increases the debt capacity of the borrowers as it mitigates the agency problem in this external financing relationship. The extent to which the borrowing constraint is relaxed by collateral pledging depends on the collateral liquidation value.

In these empirical studies, real estate prices are regarded as mere shifters of the pledgeable assets' value which determines the borrowing capacities of firms. Yet, an increase in real estate prices surely raises the value of the pledgeable assets and mitigates the agency problem but it simultaneously lowers the profit due to the increase in the cost of inputs.

In order to formalize the causal impact of real estate prices on productive investment, we propose a simple partial equilibrium model of investment subject to a credit rationing that results from moral hazard and where real estate assets are both pledged and used as an input in the production process. In this model, a representative firm optimally chooses its level of investment subject to an endogenous borrowing constraint that is derived from the incentive compatibility (between the lender and the borrower) and the lender rationality constraints. When the endogenous borrowing capacity is binding, we show that the sign and the magnitude of the effect of real estate prices on investment are determined by the volume of real estate holdings of the firm. When prices increase, firms owning few real estate assets suffer from a negative profit channel without significantly benefiting from a positive collateral channel; conversely, firms owning more real estate assets face a less stringent profit channel and amply benefit from the collateral channel.

Figure: The heterogeneous effects of real estate prices on corporate investment: real estate holdings are the key determinant

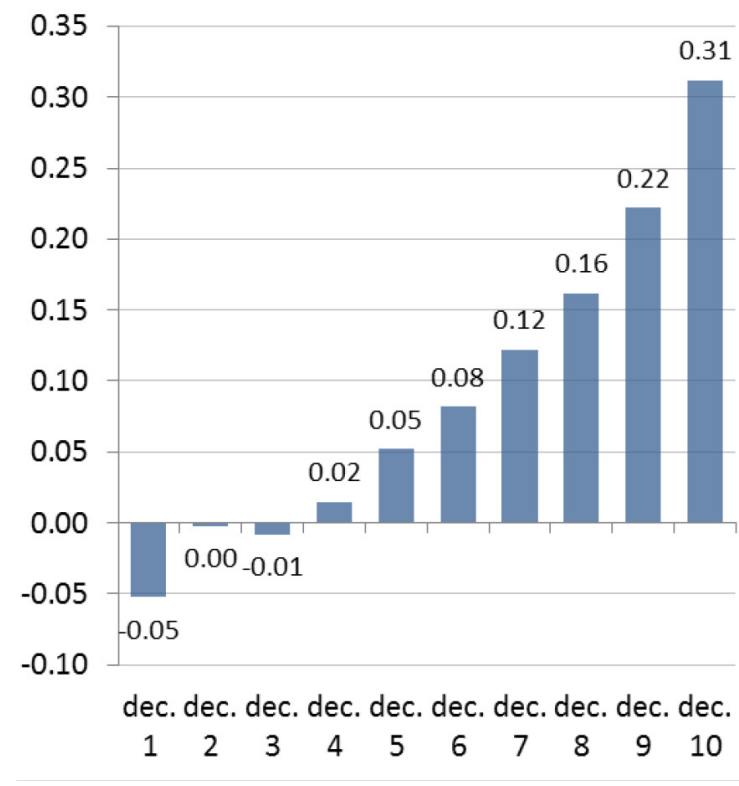

Notes: This graph plots the estimates of the coefficients associated with the log value of local real estate prices for the different deciles of real-estate holdings when the dependent variable is the productive investment rate. Sources: Fiben, INSEE and authors' computation. 
We use a large French firm database to confront these predictions with the data. France is a particularly relevant case to test these theoretical predictions as it experienced both a very steep, and yet uncorrected increase in real estate prices.

We contribute to the existing literature by showing that the sign and the magnitude of the effect of real estate prices on productive investment are driven by real estate holdings. We notably show that real estate prices have heterogeneous effects on productive investment depending on the position of the firms in the 2-digit sectoral distributions of a normalized measure of real estate holdings (see the graph presented above). We find a negative impact of an increase in real estate prices on productive investment at the bottom of the distribution, while the effect is highly positive at the upper end of the distribution. Our preferred estimates indicate that a $10 \%$ increase in real estate prices causes a $1 \%$ decrease in the investment rate of firms in the first decile of the distribution but a $6 \%$ increase in the investment rate of firms belonging to the last decile. Our empirical results also suggest that the impact of an increase in real estate prices on aggregate productive capital is positive. The documented heterogeneous effects across firms could link real estate prices dynamics to suboptimal allocation of inputs.

\section{PRIX DE L'IMMOBILIER ET INVESTISSEMENT DES ENTREPRISES : THÉORIE ET ÉLÉMENTS DE PREUVE EMPIRIQUE DES EFFETS HÉTÉROGÈNES}

\section{RÉSUMÉ}

Dans cet article, nous étudions les effets des prix de l'immobilier sur l'investissement productif des entreprises. Nous proposons un cadre théorique simple qui permet de rendre compte de l'investissement des entreprises en présence de contraintes de crédit fondées sur le collatéral immobilier. Nous montrons que les prix de l'immobilier influent sur la capacité d'investissement des entreprises via deux canaux. Une hausse des prix accroit la valeur de marché de l'actif collatéralisable et atténue les effets du problème de type principal-agent qui caractérise la relation entre le créditeur et l'entrepreneur. Simultanément, cette hausse diminue le profit attendu du fait de l'accroissement du coût d'un facteur de production. Alors que la littérature s'est principalement intéressée à ce premier canal, l'identification du second met en lumière l'effet potentiellement hétérogène de la dynamique des prix de l'immobilier sur l'investissement des entreprises. En mobilisant une base de données d'entreprises françaises, nous trouvons des effets hétérogènes des prix de l'immobilier sur l'investissement des entreprises selon leur position dans la distribution sectorielle du niveau de détention d'actifs immobiliers. Une hausse de $10 \%$ des prix de l'immobilier induit une baisse de $1 \%$ du taux d'investissement des entreprises situées dans le premier décile alors que cette même hausse accroît de $6 \%$ le taux d'investissement des entreprises situées dans le dernier décile.

Mots-clés : Investissement des entreprises, prix de l'immobilier, canal du collatéral, contrainte financière.

Les Documents de travail reflètent les idées personnelles de leurs auteurs et n'expriment pas nécessairement la position de la Banque de France. Ce document est disponible sur publications.banquefrance.fr 


\section{Introduction}

This paper estimates the effect of real estate prices on productive investment (i.e., machines, equipment and intangible assets), focusing on potential heterogeneous impacts depending on the composition of the firms' assets.

From the late nineties to the financial crisis, real estate prices in many advanced countries have experienced a boom, unprecedented in size and duration. These booms led to significant capital misallocation across sectors and firms (Cette, Fernald, and Mojon, 2016). In France, despite a decrease during the crisis, the price level remains much higher than in the nineties relative to consumer or equipment prices and the question is raised as to the impact of the real estate prices boom on sectoral allocation and on productive investment (Askenazy, 2013).

While the literature has focused on the collateral channel of real estate prices, with monotonous effects on investment, we take into account both this collateral channel and a factor cost channel, which yield heterogeneous effects of real estate prices on productive investment of credit-constrained firms. These results are theoretically formalized and substantiated by empirical analyses performed on a large French firm-level database. We show that both the sign and the magnitude of their effect depend on the firms' real estate holdings.

In an imperfect credit market, collateral pledging enhances the firms' borrowing capacities. The ability of the lenders to seize pledged collateral increases the debt capacity of the borrowers as it mitigates the agency problem in this external financing relationship (Berger and Udell, 1990). The extent to which the borrowing constraint is relaxed by collateral pledging depends on the collateral liquidation value. Real estate assets often constitute the bulk of the firms's pledgeable assets since they are easily redeployable and have a long lifespan. Collecting data on the financing behavior of 91 banks in 45 countries, Beck, Demirgüç-Kunt, and Martinez Peria (2008) find that more than three-quarters of banks require collateral to make business loans and that real estate is the most frequently accepted type of collateral for business lending, regardless of firms' size. Through this mechanism, an increase in real estate prices is expected to relax the firms' borrowing constraint and to ease their funding.

The role of this collateral channel has been extensively discussed in the literature on macroeconomic fluctuations. For instance, Kiyotaki and Moore (1997) show how the interaction between credit limits and asset prices is a powerful transmission mechanism which explains large and persistent comovements in output and asset prices through investment dynamics. Recent macroeconomic contributions have shed light on the link between land prices and business investment. Liu, Wang, and Zha (2013) develop a macroeconomic model where land is used as a collateral by credit constrained firms. When they estimate their model on aggregate US data, they find that the joint dynamics of land prices and investment is an important mechanism that amplifies and propagates macroeconomic fluctuations. Kaas, Pintus, and Ray (2014) also provide empirical evidence of such a mechanism using aggregate data from France.

The positive causal relationship between real estate prices and corporate investment, channeled by the collateral value, has also been empirically examined using firm-level data. Based on a large sample of publicly-listed firms in Japan, Gan (2007) finds a significant impact of collateral value on corporate investment during the five-year period after the land price collapse which occurred in the early 1990s. Chaney, Sraer, and Thesmar (2012) 
(hereafter CST) study the sensitivity of investment to real estate collateral value by using data from a sample of US publicly-listed firms observed between 1993 and 2007. They find a substantial causal relationship between collateral value and business investment at the firm level. In a recent contribution focusing on labor market variables, Chaney, Sraer, and Thesmar (2013) document a significant real estate collateral channel by considering a large database of French firms observed over the period 1998-2007. Interestingly enough, Wu, Gyourko, and Deng (2015) find no evidence of such a mechanism for Chinese firms, suggesting that the transmission mechanism from real estate prices to corporate investment essentially works through credit market frictions. Indeed, the authors argue that the collateral channel may be altered in the Chinese case by the role played by state-owned enterprises and government-controlled banks.

In these empirical studies, real estate prices are regarded as mere shifters of the pledgeable assets' value which determines the borrowing capacities of firms. This view relies on the credit rationing mechanism, put forward by Hart and Moore (1990) and built around the idea that, because loan agreement can be renegotiated and the entrepreneur is required for the completion of the project, the borrowing capacity only depends on the anticipated liquidation value of the asset that the lender can seize. In this framework, asset prices have an unambiguous positive effect on the borrowing capacities of firms.

Yet, when as a result of the agency problem characterizing the creditor-entrepreneur relationship, the borrowing capacity is determined by the expected value of pledged assets along with the expected firms' profit (Tirole, 2010), real estate prices have an equivocal impact on borrowing capacities. Indeed, real estate prices draw the two components of this borrowing capacity in opposite directions: an increase in real estate prices raises the value of the pledgeable assets and mitigates the agency problem but it simultaneously lowers their profit due to the increase in the cost of inputs.

In order to formalize the link between real estate prices and productive investment, we propose a simple partial equilibrium model of investment subject to a credit rationing that results from moral hazard and where real estate assets are both pledged and used as an input in the production process. When investment is determined by the endogenous borrowing capacity, we show that the sign and magnitude of the effect of real estate prices on investment are determined by the volume of real estate holdings of the firm. When prices increase, firms owning few real estate assets suffer from a negative profit channel without significantly benefiting from a positive collateral channel; conversely, firms owning more real estate assets face a less stringent profit channel and amply benefit from the collateral channel.

We use a large French firm database to confront these predictions with the data. France is a particularly relevant case to test these theoretical predictions as it experienced both a very steep, and yet uncorrected increase in real estate prices, while it registered growing signs of misallocations, in particular through increasing productivity dispersion across firms (Cette, Corde, and Lecat, 2017). When estimating the effect of real estate prices on productive investment, we face an identification issue resulting from the fact that real estate prices comove with the business cycle. More specifically, we know that the level of bank credits affect both investment and real estate prices (Mora, 2008 and Favara and Imbs, 2015). Thus, real estate prices are correlated with investment opportunities. Following Case, Quigley, and Shiller (2005) and CST, our identification strategy is twofold. First, we analyze the 
effect of real estate prices at the département level $^{1}$ on investment, which is not necessarily limited to the département boundaries. Large firms operating at the national level are expected to face similar economic conditions but their borrowing capacities follow different paths depending on the dynamics of local real estate prices, namely in the département where the firms' real estate assets are located. Second, within a département where firms face the same local economic conditions and thus similar investment opportunities, we can compare the impact of real estate prices on productive investment across firms with varying level of real estate holdings.

We contribute to the existing literature by showing that, in accordance with the results derived from a theoretical model with an endogenous borrowing constraint taking into account firms' profit, the sign and magnitude of the effect of real estate prices on productive investment are determined by real estate holdings. In particular, we show that real estate prices have heterogeneous effects on productive investment depending on the position of the firms in the 2-digit sectoral distributions of a normalized measure of real estate holdings. We find a negative impact of an increase in real estate prices on productive investment at the bottom of the distribution, while the effect is highly positive at the upper end of the distribution. Our preferred estimates indicate that a $10 \%$ increase in real estate prices causes a $1 \%$ decrease in the investment rate of firms in the first decile of the distribution but a $6 \%$ increase in the investment rate of firms belonging to the last decile. Our empirical results also suggest that the impact of an increase in real estate prices on aggregate productive capital is positive. Nevertheless, the documented heterogeneous effects across the real estate holdings distribution could link real estate prices dynamics to misallocation of capital.

Our paper is organized as follows. Section 2 presents a tool model from which we derive our main testable predictions. Section 3 presents data sources and variables. Section 4 reports and comments our empirical findings. Section 5 concludes.

\section{A simple theoretical framework}

We develop a simple model of firms' productive investment with credit rationing and real estate collateral in the spirit of the one proposed by Chaney, Sraer, and Thesmar (2009). Nevertheless, we introduce two substantial changes that alter the effect of real estate prices on the productive investment of credit-constrained firms. First, we consider an alternative micro-founded borrowing constraint based on the moral hazard mechanism puts forward by Tirole (2010). Second, we treat real estate assets as inputs in the firms' production process.

\subsection{Model setup}

In this model, we consider a risk-neutral representative Firm (the "Entrepreneur" or "Borrower") in a small open economy ; the risk free interest rate is $r>0$. The Firm is assumed to have a finite horizon and the model has only two dates that correspond to the beginning and the end of a period.

At the beginning of the period, the representative Firm is endowed with capital $k_{0}$, cash-flow $c_{0}$ (in units of capital), outstanding debt $B_{0}$ (in units of capital) owing to an external investor, and $R_{0}$ real estate units. The net debt is defined as the outstanding debt

\footnotetext{
${ }^{1} \mathrm{~A}$ département is an administrative zone. There are 95 départements in France. Each of them has approximately the same geographical size (6,000 square kilometers), but different population sizes.
} 
minus the cash-flow, hence $N B_{0}=B_{0}-c_{0} \cdot{ }^{2}$ The Firm can invest at the beginning of the period in a project that yields gross revenue $y(k, R, \theta)$ at the end of the period; $k$ is the Firm's capital made of the initial capital and the investment, hence $k=k_{0}+i$ where $i$ is the investment at the beginning of the period; $R$ is the amount of real estate units used by the Firm and $\theta$ is the Firm's productivity, with $\theta \in[\underline{\theta}, \bar{\theta}] .^{3}$ The revenue function is twice differentiable, increasing with $k, R$ and $\theta$, and concave with $k, R$ and $\theta$. Capital and real estate are also assumed to be partially substitutable and therefore $y_{k R}>0$.

The Firm must choose at the beginning of the period the amount of real estate units used in its production process. To modulate the real estate facilities, the Firm has access to a perfectly competitive real estate market and contracts with an outside risk-neutral counterpart either to rent or to lend real estate units. We denote $r^{l}$ the renting cost of one unit of real estate over the period; a simple no-arbitrage condition gives $r^{l}=r p$, where $p$ is the market price of one real estate unit (in units of capital), with $p \in[p, \bar{p}]{ }^{4}$ The function $c_{r e}$ denotes the Firm's real estate cost paid at the end of the period. Note that these real estate costs can also be thought as the user cost of real estate capital of a Firm that borrows at the risk free interest rate. From what precedes, we have $c_{r e}(R)=r p\left(R-R_{0}\right)$.

At the end of the period, the Firm is liquidated. The liquidation value corresponds to the market value of the real estate assets as we assume that $k$ has no outside value.

\subsection{Credit rationing}

The Firm may need external financing if the initial cash-flow is insufficient to finance investment. The Firm can contract with a deep-pocket, risk-neutral external Investor (or "the Lender"); the Lender behaves competitively in the sense that the loan, if any, makes no profit. A financing contract specifies two transfers $\left(b_{0} ; b_{1}\right) \in \mathbb{R}^{2}$ from the Firm to the Investor; $b_{0}$ occurs at the beginning of the period and $b_{1}$ at the end of the period. They satisfy the condition $b_{0}+\frac{b_{1}}{1+r} \geq B_{0} .^{5}$

An essential feature of our model is that the Firm faces credit rationing. Some profitable investments may not receive funding. This credit rationing is driven by the asymmetry of information between borrowers and lenders. The mechanism of credit rationing that we introduce is similar to the one set forth by Tirole (2010). The Lender faces an agency problem as the Firm (or "the Borrower") may mismanage the project. The Borrower can either "behave" or "misbehave". Behaving yields the above-described revenue $y$ and no private benefit to the Firm. Misbehaving generates a private benefit $S>0$ (measured in units of capital) to the Entrepreneur that can be interpreted as disutility of effort saved by the Entrepreneur when shirking. This private benefit damages the profitability of the project and induces a fixed loss compared to the optimal revenue; the project yields $y-L$ when the Entrepreneur misbehaves. It is inefficient in the sense that the private benefit to

\footnotetext{
${ }^{2}$ We assume $k_{0} \in\left[0, \overline{k_{0}}\right] ; c_{0} \in\left[0, \overline{c_{0}}\right] ; B_{0} \in\left[0, \overline{B_{0}}\right]$ and $R_{0} \in\left[0, \overline{R_{0}}\right]$. Restrictions on the value of $\overline{B_{0}}$ are discussed below.

${ }^{3}$ We introduce the Firm's productivity in this model because the literature on agglomeration economies has documented the link between local spatial density and productivity (see Combes and Gobillon, 2014 for a recent survey). Introducing productivity in this model renders explicit that changes in productivity can partially offset the effects of prices on factors' demand when productivity and prices comove.

${ }^{4} \mathrm{An}$ implicit hypothesis behind this renting rate is that there is no expected capital gain or loss.

${ }^{5}$ In order to discard any case of inevitable default, we assume that the net present value of the Firm is positive even if there is no initial investment. it implies an upper bound for $B_{0}$, i.e, $B_{0} \leq c_{0}+\frac{y\left(k_{0}, R, \theta\right)-c_{r e}(R)+p R_{0}}{1+r}$ or equivalently, $N B_{0} \leq \frac{y\left(k_{0}, R, \theta\right)-c_{r e}(R)+p R_{0}}{1+r}$.
} 
the Firm is smaller than the foregone revenue (i.e., $S<L$ ) but, as this private benefit is not shared with the Investor conversely to the revenue, the Firm may prefer to misbehave. We assume that their values are known by both agents. Consequently, to ensure that the Firm will not shirk, the loan agreement between the Firm and the Investor (to be defined below) must secure a sufficient stake in the outcome of the project to the Firm. Thus, the project's income cannot be fully pledged to the outside Investor and a project may not receive financing even if the expected profit, when the Firm behaves, exceeds the required investment plus the interest expenses.

In order to enhance its borrowing capacity, the Firm pledges collateral. We focus our analysis on real estate collateral as we have set the outside value of used capital to 0 . The value of collateralizable assets corresponds to the market value of the real estate assets, that is $p R_{0}$. The financing contract between the Firm and the Investor stipulates how the profit is shared as well as a contingent right for the investor to seize the real estate collateral. A share $\varphi$ of the profit goes to the Firm and a share $1-\varphi$ goes to the investor in order to pay back the loan and its interests. If the Firm defaults on the loan, that is to say if the Firm is not in a position to transfer a amount $b_{1}$ satisfying the above-mentioned condition, the investor seizes the collateral and the Firm losses the collateral pledged. ${ }^{6}$

We assume that $L$ is large enough in comparison to $S$ so that there is no profitable investment in case of a misbehavior:

$$
\left(y-c_{r e}-L+S\right)-(1+r) i<0
$$

Making this assumption, we insure that the project is funded if and only if the incentive scheme is designed so that the Entrepreneur behaves. Indeed, equation (1) implies:

$$
\left[(1-\varphi)\left(y-c_{r e}-L\right)-(1+r)\left(i-c_{0}+B_{0}\right)\right]+\left[\varphi\left(y-c_{r e}-L\right)+S-(1+r) c_{0}\right]<0
$$

In the inequality (2), when the second term within square brackets - the profit to the Firm in case of a misbehavior minus the future value of initial cash - is positive, the first term within the square brackets - the profit to the Lender in case of a misbehavior minus the future value of outstanding debt - is negative. Shirking entails defaulting and thus no loan that gives an incentive to the Firm to misbehave will be granted.

From the loan agreement's structure, we derive an incentive compatibility constraint stating that the share of the profit going to the Firm must insure that the entrepreneur is better off behaving:

$$
\varphi y \geq \varphi(y-L)+S-p R_{0}
$$

This incentive constraint defines a lower limit for $\varphi$; we denote this limit $\underline{\varphi}=\frac{S-p R_{0}}{L}$. The private benefit being smaller than the foregone revenue we have $\varphi<1$. The sign of $\varphi$, that is to say the sign of $S-p R_{0}$, is crucial as it determines whether or not credit rationing can arise. If $S-p R_{0}$ is negative, that is if the private benefit derived from shirking is lower than the market value of pledged collateral, the Borrower has no incentive to default,

\footnotetext{
${ }^{6}$ Even if the default is contemplated because it affects the incentives of the borrower, it has to be noticed that the default never occurs in this model as the loan agreement is designed to discard it (see the conditions introduced below). In this context, a contract where the share $\varphi$ would depend on the Firm's behaviour can overcome the agency problem; nonetheless we can easily think of information constraints (e.g. idiosyncratic income shocks) that would render such a contract unfeasible.
} 
regardless of the share of the profit he can secure. The Investor is thus in a position to claim the entire profit for the reimbursement of the loan and its interests, and any profitable project is funded. Conversely, if $S-p R_{0}$ is positive, depending on the share of the profit that the Firm secures, the Entrepreneur may be better off defaulting and credit rationing can arise as the Lender cannot claim the entire profit to reimburse the loan and its interests.

We derive the borrowing constraint when $\varphi \in(0,1)$. The Lender's rationality constraint implies that the share of the profit he secures through the loan agreement is higher than the amount of outstanding debt:

$$
(1-\varphi)\left(y-c_{r e}\right) \geq(1+r)\left(B_{0}-b_{0}\right)
$$

Incorporating the incentive compatibility constraint, equation (3), into the Lender's rationality constraint, equation (4) gives the following borrowing constraint: ${ }^{7}$

$$
\frac{L-S+p R_{0}}{L}\left(y(k, R, \theta)-r p\left(R-R_{0}\right)\right) \geq(1+r)\left(B_{0}-b_{0}\right)
$$

The real estate prices affect the credit limit through two channels potentially going in opposite directions. An upward change in the real estate prices increases the market value of the collateral which raises the cost associated with a default and makes it possible for the Lender to secure a higher share of the profit. Simultaneously, if $R$ is higher than $R_{0}$, the real estate costs increase and cut back the profit.

\subsection{Real estate prices and investment}

The Firm makes a decision with respect to the investment, the amount of real estate units used for production and the debt contract in order to maximize the project's net present value. If the Firm is unconstrained, its program is the following:

$$
\begin{array}{ll}
\max _{\left(i, R, b_{0}, b_{1}\right)} & c_{0}-b_{0}-i+\frac{y(k, R, \theta)-c_{r e}(R)+p R_{0}-b_{1}}{1+r} \\
\text { s.t. } & B_{0} \leq b_{0}+\frac{b_{1}}{1+r}
\end{array}
$$

By contrast, if the Firm is constrained, it is subject both to the borrowing constraint and to a liquidity constraint at the beginning of the period:

$$
\begin{array}{ll}
\max _{\left(i, R, b_{0}, b_{1}\right)} & c_{0}-b_{0}-i+\frac{y(k, R, \theta)-c_{r e}(R)+p R_{0}-b_{1}}{1+r} \\
\text { s.t. } & B_{0} \leq b_{0}+\frac{b_{1}}{1+r} \\
& (1+r)\left(B_{0}-b_{0}\right) \leq \frac{L-S+p R_{0}}{L}\left(y(k, R, \theta)-c_{r e}(R)\right) \\
& i \leq c_{0}-b_{0}
\end{array}
$$

We are interested in highlighting the predicted impact of a modification in real estate prices on the Firm's investment decision in both cases. We first focus on the case where the Firm is not affected by the borrowing constraint, which is the case when $R_{0} \geq \frac{S}{p}$, or alternatively when the borrowing constraint is not binding, which is the case if the initial

\footnotetext{
${ }^{7}$ Using this borrowing constraint and assuming that the amount of installed capital results from the Firm's history, we get another upper bound for the initial amount of the outstanding debt of constrained Firm, i.e., $B_{0} \leq \frac{L-S+p R_{0}}{(1+r) L}\left[y\left(k_{0}, R, \theta\right)-c_{r e}(R)\right]$.
} 
cash-flow is big enough to finance the optimal level of investment. This optimal level of investment, as well as the optimal number of real estate units, are given by the first order conditions of the objective function in program (6) with re ect to investment and real estate units:

$$
\begin{aligned}
& y_{k}\left(k_{0}+i^{*}, R, \theta\right)=1+r \\
& y_{R}\left(k_{0}+i, R^{*}, \theta\right)=r p
\end{aligned}
$$

where $i^{*}$ and $R^{*}$ denote the first best investment level and the first best real estate units level, respectively. Let us denote $k^{*}=k_{0}+i^{*}$. We differentiate the system with respect to real estate prices to obtain:

$$
\begin{aligned}
\frac{\partial i^{*}}{\partial p} y_{k k}\left(k^{*}, R, \theta\right) & =-\frac{\partial R}{\partial p} y_{k R}\left(k^{*}, R, \theta\right) \\
\frac{\partial R^{*}}{\partial p} & =\frac{r}{y_{R R}\left(k, R^{*}, \theta\right)}-\frac{\partial i}{\partial p} \frac{y_{R k}\left(k, R^{*}, \theta\right)}{y_{R R}\left(k, R^{*}, \theta\right)}
\end{aligned}
$$

Incorporating the second equation into the first when investment and real estate units are chosen optimally, we write:

$$
\frac{\partial i^{*}}{\partial p}\left(\frac{y_{k R}\left(k^{*}, R^{*}, \theta\right)^{2}}{y_{R R}\left(k^{*}, R^{*}, \theta\right)}-y_{k k}\left(k^{*}, R^{*}, \theta\right)\right)=r \frac{y_{k R}\left(k^{*}, R^{*}, \theta\right)}{y_{R R}\left(k^{*}, R^{*}, \theta\right)}
$$

Proposition 1 The investment of the unconstrained Firm is negatively impacted by an exogenous increase in real estate prices.

Proof. The term post-multiplying $\frac{\partial i^{*}}{\partial p}$ in the $L H S$ of equation (10) is shown to be positive in Appendix A. The standard assumptions made on function $y$ allow to deduce that $\frac{\partial i^{*}}{\partial p}<0$.

We can also show that, in the unconstrained case, investment is unaffected by the initial endowment in real estate units, in initial net debt, i.e., $\frac{\partial i^{*}}{\partial R_{0}}=\frac{\partial i^{*}}{\partial N B_{0}}=0$. The optimal investment increases with the productivity; $\frac{\partial i^{*}}{\partial \theta}>0$.

We now consider the case where the Firm is financially constrained. The constrained Firm invests less than the optimal investment $i^{*}$. The Firm is constrained when it is subject to a binding borrowing constraint. Investment and real estate units are then given by the liquidity constraint and the first order condition on real estate units, respectively:

$$
\begin{aligned}
i & =\frac{\left(L-S+p R_{0}\right)\left(y(k, R, \theta)-r p\left(R-R_{0}\right)\right)}{L(1+r)}-N B_{0} \\
y_{R}(k, R, \theta) & =r p
\end{aligned}
$$

We are interested in deriving the sign of the first derivative of the investment level with respect to real estate prices, from equation (11) we have: 


$$
\begin{aligned}
\frac{\partial i}{\partial p} & \left((1+r)-\frac{L-S+p R_{0}}{L} y_{k}(k, R, \theta)\right)= \\
& \frac{L-S+p R_{0}}{L}\left(\frac{\partial R}{\partial p}\left[y_{R}(k, R, \theta)-r p\right]-r\left(R-R_{0}\right)\right) \\
& +\frac{R_{0}}{L}\left(y(k, R, \theta)-r p\left(R-R_{0}\right)\right)
\end{aligned}
$$

Incorporating the first order condition on real estate units, we can write:

$$
\frac{\partial i}{\partial p}\left((1+r)-\frac{L-S+p R_{0}}{L} y_{k}(k, R, \theta)\right)=P\left(R_{0}\right)
$$

where:

$$
P\left(R_{0}\right)=\frac{1}{L}\left((2 r p) R_{0}^{2}+(y(k, R, \theta)-2 r p R+r(L-S)) R_{0}-r(L-S) R\right)
$$

Proposition 2 The investment of the credit-constrained Firm is positively affected by an increase in real estate prices if and only if its initial endowment in real estate units is above a positive threshold $\bar{R}$.

Proof. We show in the Appendix B that the sign of $\frac{\partial i}{\partial p}$ is given by the sign of the polynomial of degree two, $P\left(R_{0}\right)$, and that there exists a unique threshold $\bar{R}$ such that $\frac{\partial i}{\partial p} \geq 0$ if and only if $R_{0} \geq \bar{R} .^{8}$

As noted above, an increase in real estate prices has two opposite effects on the constrained Firm. First it pushes up the liquidation value the collateral, which relaxes the borrowing constraint; second, it increases the cost of real estate which negatively affects the profit and tightens the borrowing constraint. Whether the first or the second effect dominates is determined by the initial endowment in real estate units.

We can also show that, in the constrained case, $\frac{\partial i}{\partial R_{0}}>0, \frac{\partial i}{\partial N B_{0}}<0$ and $\frac{\partial i}{\partial \theta}>0$. A proof of these results is also provided in Appendix B.

\subsection{Investment equation and predictions}

We build this theoretical model in order to ease interpretation of the results derived from the reduced form approach adopted in the empirical part.

Denoting $h\left(k_{0}, N B_{0}, \theta, R_{0}, p\right)$ the policy function for $i .^{9}$ We can consider a first order linear approximation of this policy function around a firm with the median characteristics:

$$
i=h\left(k_{0}, N B_{0}, \theta, R_{0}, p\right) \approx \gamma+\nabla h(\tilde{x}) \tilde{x}^{\prime}
$$

where $\tilde{x}=\left(\tilde{k_{0}}, N B_{0}, \tilde{\theta}, \tilde{R_{0}}, \tilde{p}\right)$ represents the state variables at their median level, $\gamma$ is a constant, and $\nabla h(\tilde{x})$ is the gradient of the policy function evaluated in $\tilde{x}$. Hence:

\footnotetext{
of $y$.

${ }^{8}$ The relative position of $\bar{R}$ with respect to $\frac{S}{p}$ depends on the parameters' values and the functional form

${ }^{9}$ Notice that in the maximization program we can substitute $N B_{0}$ to $B_{0}-c_{0}$ and $B_{0}$ and $c_{0}$ disappears. The investment is thus a function of net debt.
} 


$$
i \approx \gamma+\frac{\partial h}{\partial k_{0}}(\tilde{x}) k_{0}+\frac{\partial h}{\partial N B_{0}}(\tilde{x}) N B_{0}+\frac{\partial h}{\partial \theta}(\tilde{x}) \theta+\frac{\partial h}{\partial R_{0}}(\tilde{x}) R_{0}+\frac{\partial h}{\partial p}(\tilde{x}) p
$$

From our model, we can formulate the following predictions:

i a positive estimate of the coefficient associated with the number of real estate units or a negative estimate of the coefficient associated with the amount of net debt, imply a rejection of the null hypothesis that all firms are unconstrained;

ii the sign of the estimated coefficient associated with real estate prices is expected to positively depends on the size of real estate holdings at the beginning of the period if the sample contains credit-constrained firms.

\section{Data}

We merge real estate prices at the département level with accounting data on French firms.

\subsection{Real estate prices}

Corporate real estate local prices being not available in France, we use residential prices. We find evidence that, at the national level in France, the dynamics of prices in the different segments of the real estate market, and notably residential and corporate real estate, follow a similar trend (see Figure 3 in Appendix C). ${ }^{10}$ We use the Notaires-INSEE ${ }^{11}$ apartment price indices built by Fougère and Poulhes (2012) which are based on the data collected by French notaires and the methodology developed by INSEE (i.e., the French statistical agency). These indices take into account changes in the quality of apartments since hedonic characteristics of the flats are used to build the indices. The indices in each département are standardized to be equal to 100 in 2000; département is the smallest geographic entity for which those indices are available. We introduce geographic variability using apartment per square meter prices in each département in 2013. Apartment per square meter prices at the département level are collected by the Chambre des Notaires. They correspond to the average price per square meter of all apartment transactions registered in a given year. The Chambre des Notaires de Paris has registered apartment prices in the database Bien from 1992 onwards and the Notaires de France started to register those prices for the rest of mainland France in the database Perval in 1994. We retropolate apartment prices using the apartment price index to build apartment prices per square meter at the départementlevel from 1994 onwards. Prior to 1994, housing price indices used to retropolate the series are taken from Friggit (2009). We use the Paris housing price index (available from 1840 onwards) for département located in the Paris area (Ile-de-France) and the national housing price index (available from 1936 onwards) for the other département. We report the trend of real estate prices in each département in Appendix C.

Real estate prices at the département level are less precise before 1994. We therefore start our analysis in 1994. We also restrict our study to firms headquartered in so-called

\footnotetext{
${ }^{10} C S T$ has also shown, using US data, that commercial and residential prices lead to similar results in their study.

${ }^{11}$ Solicitor is the English equivalent for the French word notaire
} 
département de France métropolitaine (mainland France), excluding overseas territories and Corsica. ${ }^{12}$

\subsection{Accounting data}

We exploit a large French firm-level database constructed by Banque de France called FiBEn. It is based on fiscal documents, including balance sheet and P\&L statements, and it contains detailed information on flow and stock accounting variables. The database includes all French firms with annual sales exceeding 750,000 euros or with outstanding credit exceeding 380,000 euros. We exclude from our sample firms operating in finance, insurance, real estate, construction, mining industries as well as public administration and social services.

We build productive investment rates, as it is standard in the investment literature (Kaplan and Zingales, 1997 or Almeida, Campello, and Weisbach, 2004), by computing the ratio of productive investment to past year property, plant and equipment stock (hereafter $P P E)$. Productive investment corresponds to capital expenditure net of real estate acquisitions; real estate acquisitions being approximated by positive variations of the gross value of real estate assets. ${ }^{13}$ PPE are deflated as follows. We recover the mean age of fixed capital by computing the ratio of accumulated amortizations over gross book value and by making an assumption on the length of the amortization period. ${ }^{14}$ Using the mean age we get the average year of acquisition. We then deflate the unamortized fixed capital by the aggregate deflator of the gross fixed capital formation of the average year of acquisition. We compute the net debt by subtracting the cash to the total financial debt. We also normalize the net debt by the PPE stock.

Using firms balance sheet information, we estimate total factor productivity (TFP) as the residual of a two-factor (fixed capital and labor) Cobb-Douglas production function. ${ }^{15}$ TFP is estimated separately for each 2-digit sector using data over the period 1994-2013. ${ }^{16}$ Our preferred measure uses the method proposed by Levinsohn and Petrin (2003).

We only keep firms that declare data over at least three consecutive years. Our panel is unbalanced as firms may enter and exit the sample between 1994 and 2013. We cannot conclude that a firm exiting the sample has gone bankrupt as it may have merely crossed the above-mentioned declaration thresholds. Alternatively, it may have been bought by another firm. The median number of employees per firm is 16 and the median revenue is 2.2 million euros. Further descriptive statistics are provided in Table (1).

\subsection{Real estate units at the firm level}

A key issue in our study is to recover the real estate units held by a firm every year. We thereafter define a real estate unit as an apartment's square meter equivalent. Real estate

\footnotetext{
${ }^{12}$ We also exclude firms headquartered in Aveyron, in Lot and in Mayenne as the housing price indices for those département are based on too few observations at the beginning of the studied period.

${ }^{13}$ These variations may not exactly correspond to real estate asset acquisition as they may include some disposals.

${ }^{14}$ We retain an average amortization period of 10 years; this assumption reflects the fact that fixed capital is made of both equipments and buildings. Our results are not sensitive to this assumption.

${ }^{15}$ Total Factor Productivity is here the portion of output not explained by the amount of inputs used in production. As such, its level is determined by how efficiently and intensely the inputs are utilized in production.

${ }^{16}$ We use the NACE 2 classification of INSEE.
} 
Table 1: Descriptive statistics of the main variables

\begin{tabular}{l|c|c|c|c|c|c|c|c}
\hline \hline & $\mathrm{N}$ & Mean & S. D. & Min & Q1 & p50 & Q3 & Max \\
\hline Sales & $1,534,721$ & 10,959 & 166,779 & 0 & 1,275 & 2,198 & 4,987 & $34,608,167$ \\
Numbers of employees & $1,534,721$ & 56.67 & 701.75 & 1 & 9 & 16 & 34 & 152,586 \\
Productive investment ratio & $1,497,095$ & 0.62 & 1.39 & 0.00 & 0.08 & 0.23 & 0.58 & 19.65 \\
NREH & $1,532,139$ & 0.47 & 0.96 & 0.00 & 0.00 & 0.00 & 0.55 & 8.88 \\
Net debt & $1,487,184$ & 0.60 & 6.46 & -44.69 & -0.57 & 0.34 & 1.24 & 80.93 \\
TFP & $1,525,543$ & 4.79 & 0.56 & 1.76 & 4.43 & 4.74 & 5.11 & 8.97 \\
\hline \hline
\end{tabular}

Notes: The sales are in thousand euros. The number of employees in full time equivalent. The NREH, in $m^{2}$ per thousand euros, is defined below (see equation 18) as the Normalized Real-Estate Holdings. The net debt is normalized by the PPE stock. The TFP is estimated separately for each 2- digit sector using the method proposed byLevinsohn and Petrin (2003). Sources: FiBEn.

assets reported in the balance sheet are not mark-to-market. Hence, depending on the purchase date of real estate assets, the gross value reported in the firms' balance sheets corresponds to different amounts of real estate units.

Firms' balance sheets provide information on gross value of land and buildings and accumulated amortizations of buildings. ${ }^{17}$ The mean age of real estate assets is computed thanks to the ratio of the accumulated amortizations of buildings over the gross book value of buildings:

$$
A g e_{i t}=\frac{A c c u A m_{i t}}{g r o s s B V_{i t}} N o r m A m
$$

where $A g e_{i t}$ is the mean age of real estate assets held by firm $i$ in year $t, A c c u A m_{i t}$ is the accumulated amortization of buildings, $G \operatorname{ross} B V_{i t}$ is the gross book value of buildings and Norm Am is the normative amortization period. Assuming that buildings are linearly amortized over 25 years $^{18}$, we can deduce for each firm $\times$ year observation the mean age of the real estate assets. For example, if the ratio of amortizations over the gross book value equals one fifth, we deduce that the mean age of the real estate assets is five years. When a firm holds both land and buildings, the mean age of land is assumed to be the same as the buildings' one. The mean age of the buildings in our sample is around 13.7 years. Notice that implementing this methodology requires observing price indices from 1969 onwards in

\footnotetext{
${ }^{17}$ The gross value of land and buildings corresponds to their historical value adjusted by accounting reevaluations. We are interested in historical value as we use this historical value combined with the mean age of real estate assets to recover the number of real estate units held by the firms. We can keep trace of accounting reevaluations because these operations are offset by dedicated accounts on the liability side "reevaluation surplus" for non-depreciable assets and "regulated reserves" for depreciable assets. From these accounts we compute the total amount of historical reevaluations. Unfortunately, we do not know which assets have been reevaluated. We thus reallocate the total amount of reevaluations to land and buildings based on the share of land in the gross non-depreciable assets and on the share of gross buildings in the gross depreciable assets. This assumption is coherent with the compulsory accounting reevaluations which occurred in 1976 in France. Overall, these reevaluations have a limited impact on the value of land and buildings as reevaluations allocated to real estate assets through this method account for less than $1 \%$ of the gross value of real estate assets.

${ }^{18}$ The accounting standard for the length of the amortization period depends on the nature of the buildings. Following Chaney, Sraer, and Thesmar (2013), we retain an average length of 25 years.
} 
each département. ${ }^{19}$

We do not have precise information on the location of the firms real estate assets. We use the département where the firms are headquartered as a proxy for the location of real estate assets. The validity of this approximation is supported by the fact that, given the size of the median firm in our database, establishments tend to be clustered in the headquarters' département, and that the headquarters are likely to account for an important share of the real estate holdings value. Nevertheless, we perform robustness checks by restricting our analysis to single-establishment firms, that is to say firms for which the assumption on the real estate assets' location is undoubtedly trustworthy.

In order to compute the amount of real estate units held by the firms, we divide the historical value of real estate holdings by the real estate prices in the headquarters' département at the date when, on average, real estate assets were purchased. We eventually obtain, for each firm $\times$ year observation, the number of real estate units held by the firms. We normalize this value by $P P E$ in order to have a synthetic indicator of real estate ownership which is comparable across firms. We can think of this variable as the number of square meters per thousand euros of physical capital. It is hereafter called the Normalized Real-Estate Holdings (NREH):

$$
N R E H_{i t}^{d}=\frac{A c q R E_{i t}^{d}}{\operatorname{Price}_{\text {AcqYear } i t}^{d}} \frac{1}{P P E_{i t-1}}
$$

where $N R E H_{i t}^{d}$ is the normalized real estate holdings for firm $i$ in year $t$ and département $d, A c q R E_{i t}^{d}$ is the acquisition value of real estate assets, Price $_{\text {AcqY }}^{d}$ ear $_{i t}$ is the price index in département $d$ in the mean acquisition year ${ }^{20}$ and $P P E_{i t-1}$ is the $P P E$ stock of firm $i$ in year $t-1$.

The validity of our measurement of NREH strongly relies on the accuracy of the hypothesis made on the length of the amortization period of buildings. The choice of this parameter can be questioned since the amortization rates depend on the nature of the buildings. In our baseline analysis we retain 25 years, which corresponds to the rate commonly applied for office buildings ${ }^{21}$ and the rate used by Chaney, Sraer, and Thesmar (2013) in their study on French data. As a robustness check, we estimate our model using NREH series computed with alternative amortization rates (specifically, $3 \%$ and $5 \%$ instead of $4 \%$ ).

We leave out observations whose value is above the 99th and below the 1st percentiles of the productive investment ratio, the normalized net debt, labor productivity and employment to $P P E$ ratio. We also leave out observations whose value is above the 99th percentile of the NREH distribution in order to remove outliers. Main summary statistics are reported in table 1.

\subsection{The distribution of normalized real estate holding}

A key result derived from our theoretical approach is that the investment of credit-constrained firms react differently to real estate price shocks according to the size of their real estate holdings. We hence examine whether the impact of real estate prices on investment depends on the position of the firms in the distribution of the $N R E H$ defined in equation (18).

\footnotetext{
${ }^{19}$ This is the reason why we have extended the series of the Notaires-INSEE indices.

${ }^{20}$ The acquisition year is recovered by subtracting the integer value of the computed age of real estate assets to the current year. Thus, the acquisition year is defined as $A c q Y e a r_{i t}=t-\left\llcorner A g e_{i t}\right\lrcorner$.

${ }^{21}$ See the ruling by the Conseil d'État dated 12 January 1983, number 32728.
} 
Parameters of the production function may vary over time and across sectors. Indeed, the median NREH widely differs across sectors (e.g., Figure 1). The ratio of the highest sectoral median (manufacture of leather and leather products) to the lowest sectoral one (water transport services) is equal to $9 .{ }^{22}$ We hence consider sectoral distributions. Besides, we focus on the distribution of real estate holdings for firms that own real estate assets. We sort firms holding real estate in the decile corresponding to the position of their NREH in the 2-digit sectoral distributions in a given year. ${ }^{23}$ Figure 1 represents the NREH distribution in the land transportation industry and in the wholesale trade industry.

Alternatively, we may consider distances to sectoral benchmarks. ${ }^{24}$ This alternative method does not affect the results reported below.

\subsection{The non-real estate-holding firms}

In our sample, for 52 percent of the firm $\times$ year observations, no real estate assets are reported in the balance sheet. It might be the case that some real estate assets actually held by firms are not identified in our database. Indeed, our firm-level data provide information on social financial statements but we have no information on consolidated accounts at the group level. Consequently, we do not observe real estate assets held by partially or fully owned real estate subsidiaries. It may be a source for concern because the practice of gathering real estate assets into dedicated legal structures is common in France since the beginning of the eighties. The number of real estate partnerships (Sociétés Civiles Immobilières, hereafter $S C I$ ) registered in France has soared from c.11,000 in 1978 to c.1.3 million in 2014.

We report in Appendix D the evolution since 1978 of the number of registered $S C I$. According to the French notaires benefits associated with this practice range from the ease of disposals and transmissions to potential fiscal incentives due to tax deductible loan interests. This measurement issue is more likely to affect $N R E H$ at the extensive margin (owning real estate or not) than at the intensive margin. Indeed, when firms set up dedicated legal structures to hold real estate assets, they are unlikely to retain real estate assets in their balance sheets dedicated to their core business activities. Taking this issue into account would have obliged us to specify a two-equation selection model (for instance, a dynamic Tobit-2 model) whose identification should have relied on the existence of a valid instrument affecting the ownership of real estate assets in a given year without affecting the volume of real estate. We do not have such an instrument. That is the reason why we treat non-real estate-holding firms separately.

\footnotetext{
${ }^{22}$ These statistics correspond to the sample restricted to firms owning real estate assets.

${ }^{23}$ This approach requires that we accept to discard the few sectors for which we do not have enough observations for some years.

${ }^{24}$ We recover the median value of the $N R E H$ for each 2 -digit sector in a given year. This median can be viewed as an annual reference level for real estate holdings in each industry. We compute the distance between each firm $\times$ year NREH observation and the relevant sectoral benchmark. We then assign to each firm $\times$ year observation the decile corresponding to the rank of the above-described distance within the distribution of all computed distances. Using this method, we assume that there exist a unique real estate market.
} 
Figure 1: NREH sectoral distributions - Two examples
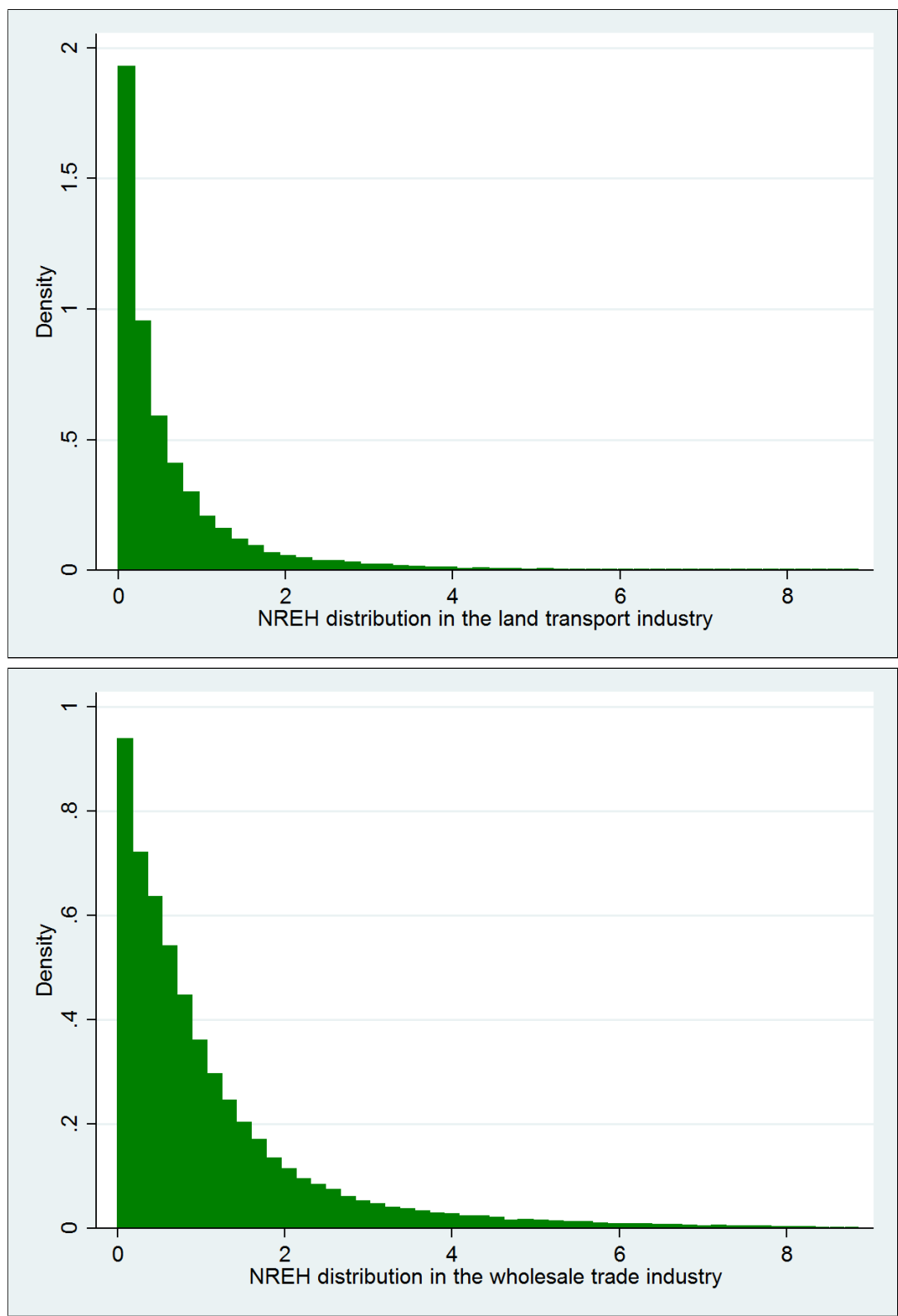

Notes:This figures plot the $N R E H$ distribution for all firm $\times$ year observations in the land transportation industry (division 49 in the NACE 2 classification of INSEE)- top panel - and in the wholesale trade industry (division 46 in the NACE 2 classification of INSEE) - bottom panel. To choose those sectors we have ranked sectors according to their NREH sectoral median. Among the $25 \%$ lowest and the $25 \%$ highest values of those medians, we have selected the sector with the highest number of observations. Sources: FiBEn. 


\section{The effects of real estate prices}

We analyze the effect of real estate prices on corporate investment at the firm level. Our empirical analysis is based on our theoretical model.

\subsection{Estimating the investment equation}

We first estimate the reduced-form equation (16) presented in section 2.4. More specifically, the estimated investment equation in year $t$ for a firm $i$ headquartered in département $d$ is:

$$
\operatorname{Inv}_{i t}=\alpha_{i}+\gamma_{t}+\beta_{1} N R E H_{i t-1}^{d}+\beta_{2} \operatorname{lnPrice}_{t}^{d}+\beta_{3} N e t D e b t_{i t-1}+\beta_{4} T F P_{i t-1}+\epsilon_{i t}
$$

where:

- $I n v_{i t}$ is firm's $i$ capital expenditure net of real estate acquisitions normalized by the $P P E$ stock in period $t-1$;

- $N R E H_{i t-1}^{d}$ is the number of real estate units held by firm $i$ at the end of year $t-1$, normalized by the $P P E$ stock in period $t-1$ as defined in equation 18;

- $\ln$ Price $e_{t}^{d}$ is the logarithm of the real estate transaction price per square meter in département $d$ in year $t$;

- NetDebtit-1 is firm's $i$ total financial debt minus cash holdings of firm $i$ at the end of year $t-1$ normalized by the $P P E$ stock in period $t-1$;

- $T F P_{i t-1}$ is firm's $i$ total factor of productivity in $t-1$ estimated by using the method introduced by Levinsohn and Petrin (2003);

As suggested by our theoretical framework, we aggregate financial debt and cash holdings. ${ }^{25}$ We include firms fixed-effects (hereafter, FE), which are assumed to control for all the time invariant unobserved firms' characteristics, and year dummies which control for economic conditions at the aggregate level. We allow for possible correlations between the shocks $\epsilon_{i t}$ at the département $\times$ year level. ${ }^{26}$

To validate empirically the theoretical prediction regarding the effect of real estate prices on corporate investment, we allow real estate prices to have differentiated effects depending on the firms' position in the NREH distribution. For that purpose, we introduce interaction terms between real estate prices and $N R E H$ deciles. We estimate the following equation:

\footnotetext{
${ }^{25}$ Besides, this specification allows to take into account the fact that firms may contract loans to finance investment in the accounting period preceding the investment. In that case, an increase in the financial debt will be positively correlated with investment in the subsequent period. It may hide the fact that higher leverages lessen firms' capacity to finance investment. Aggregating financial debt and cash holdings is an easy way to overcome this issue. Indeed, if proceeds from the loans are not used to finance investment in the contemporaneous accounting period, they will inflate cash holdings and have no impact on the net debt (computed as the financial debt minus the cash).

${ }^{26}$ Interpretations of $\beta_{1}, \beta_{2}, \beta_{3}$ and $\beta_{4}$ are derived from the model. The coefficient $\beta_{1}$ is expected to be positive if the sample contains constrained firms. It reflects the fact that constrained firms can relax their borrowing constraint through real estate assets pledging. As shown in section 2, the coefficient $\beta_{2}$ is expected to be negative for unconstrained firms and to depend on the amount of real estate units held by the constrained firms. The coefficient $\beta_{3}$ is also expected to be negative if the sample contains constrained firms. The coefficient $\beta_{4}$ is expected to be positive.
} 


$$
\begin{aligned}
\text { Inv }_{i t} & =\alpha_{i}+\gamma_{t}+\beta_{1} N R E H_{i t-1}^{d}+\sum_{j=1}^{10} \beta_{2}^{j} D_{i t-1}^{j} \text { Price }_{t}^{d}+\sum_{j=1}^{10} \lambda_{j} D_{i t-1}^{j} \\
& +\beta_{3} \text { NetDebt } i t-1+\beta_{4} \text { TFP } \text { P }_{i t-1}+\epsilon_{i t}
\end{aligned}
$$

where $D_{i t-1}^{j}$ for $i=1, \ldots, 10$ is a dummy variable indicating if the firms' $N R E H$ belongs to the $i$-th decile of the distribution.

We report in Table 2 parameter estimates of equation (19). Column 1 corresponds to the OLS estimation of equation (19). The parameter estimates associated with the NREH is found to be positive. The baseline coefficient is 0.12 , meaning that one additional square meter increases, on average, yearly investment by 120 euros. The estimated coefficient associated with net debt is negative: each additional 1 euro of net debt decreases yearly investment by 0.6 cent. The coefficient associated with productivity is positive. These coefficients are all statistically significant at the 1 percent level. The estimated coefficient associated with real estate prices is positive but not significant. Those estimates are consistent with the predictions derived from our theoretical framework. Column 2 corresponds to the same estimation with year dummies. Introducing year dummies affects the coefficient associated with real estate prices which now becomes statistically significant at the $5 \%$ level. On average, a $10 \%$ increase in real estate price translates into a 0.35 percentage point increase in the investment ratio; that corresponds to $1.5 \%$ of the median investment ratio. Other coefficients remain largely unaffected. Column 3 corresponds to the same estimation with year $\times$ sector dummies. Sectoral dynamics at the aggregate level may affect the path of corporate investment; these sectoral shocks are captured by the year $\times$ sector dummies. The coefficients remain unchanged. Column 4 reports parameter estimates of equation (19) for single-establishment firms. The assumption made on the location of real estate assets (the département where the firms are headquartered) is strong. Nevertheless, it is unquestionably true for firms operating only in one establishment. Splitting the sample between multiple and single-establishment firms allows to appraise the importance of this assumption. Estimates of the coefficients are largely unaffected when we restrict the sample to single-establishment firms. Columns 5 and 6 explore firms' behavior depending on their size; they present parameter estimates of equation (19) for small and large firms, respectively. Small firms are defined as firms reporting, in the initial observation year, a revenue below the 25th percentile of revenues in the corresponding year, and large firms are the ones reporting an initial revenue above the 75 th percentile. The estimate coefficient associated with $N R E H$ is higher for small firms than for large firms, and statistically significant at the 1 percent level for both samples. Small firms being more likely to be credit constrained than large firms, this result is perfectly in line with our theoretical predictions. Also in accordance with our expectations, the absolute value of the estimated coefficient associated with net debt is higher for small firms. The estimated coefficient associated with real estate prices is positive and statistically significant at the 1 percent level for large firms, and negative and not significant for small firms. The effects of real estate prices appear to be heterogeneous.

As mentioned above, the group made of non-real estate-holding firms includes also firms that might own some real estate assets through subsidiaries. Heterogeneity among this group may bias our estimates. We hence present in Table 3 the same estimates for the subsample of firms holding real estate assets.

To elaborate on heterogeneous effects of prices on corporate investment, we estimate equation (20) and report the results in Table 4. 
Table 2: Real estate holdings, prices and investment behavior - All firms

\begin{tabular}{lcccccc}
\hline \hline & $(1)$ & $(2)$ & $(3)$ & $(4)$ & $(5)$ & $(6)$ \\
\hline NREH & $.12^{* * *}$ & $.12^{* * *}$ & $.12^{* * *}$ & $.12^{* * *}$ & $.16^{* * *}$ & $.10^{* * *}$ \\
& $(.003)$ & $(.004)$ & $(.004)$ & $(.004)$ & $(.008)$ & $(.005)$ \\
Real-Estate prices & .01 & $.035^{* *}$ & $.029^{* *}$ & $.034^{*}$ & -.017 & $.087^{* * *}$ \\
& $(.006)$ & $(.015)$ & $(.014)$ & $(.018)$ & $(.029)$ & $(.020)$ \\
Net debt & $-.006^{* * *}$ & $-.006^{* * *}$ & $-.006^{* * *}$ & $-.005^{* * *}$ & $-.006^{* * *}$ & $-.002^{*}$ \\
& $(.001)$ & $(.001)$ & $(.001)$ & $(.001)$ & $(.002)$ & $(.001)$ \\
TFP & $.039^{* * *}$ & $.038^{* * *}$ & $.033^{* * *}$ & $.042^{* * *}$ & $.073^{* * *}$ & .009 \\
& $(.005)$ & $(.005)$ & $(.005)$ & $(.005)$ & $(.012)$ & $(.008)$ \\
\cline { 2 - 7 } Fixed effects: & & & & & & \\
Firm fixed-effects & Yes & Yes & Yes & Yes & Yes & Yes \\
Year dummies & No & Yes & No & Yes & Yes & Yes \\
Year $\times$ sector dummies & No & No & Yes & No & No & No \\
\cline { 2 - 7 } Observations & $1,447,299$ & $1,447,299$ & $1,447,299$ & $1,177,846$ & 315,768 & 410,210 \\
Adjusted $R^{2}$ & .16 & .16 & .16 & .14 & .13 & .20 \\
\hline \hline
\end{tabular}

Notes: $* * *$ pvalue $<0.01, * *$ pvalue $<0.05, *$ pvalue $<0.10$.

Robust standard errors in brackets.

Notes: The dependent variable is capital expenditure net of real estate acquisition normalized by the $P P E$ stock in year $t-1$. Column 1 is an OLS estimation of equation (19) without year dummies. Column 2 corresponds to the same equation with year dummies. Column 3 introduces also year $\times$ sector dummies. Column 4 reports the estimates of equation (19) for single-establishment firms. Columns 5 and 6 present the estimates of equation (19) for "small" and "large" firms, respectively. Sources: FiBEn. 
Table 3: Real estate holdings, prices and investment behavior - Real estate holding firms

\begin{tabular}{lcccccc}
\hline \hline & $(1)$ & $(2)$ & $(3)$ & $(4)$ & $(5)$ & $(6)$ \\
\hline NREH & $.17^{* * *}$ & $.17^{* * *}$ & $.17^{* * *}$ & $.17^{* * *}$ & $.22^{* * *}$ & $.14^{* * *}$ \\
& $(.003)$ & $(.004)$ & $(.004)$ & $(.004)$ & $(.008)$ & $(.005)$ \\
Real estate prices & $.027^{* * *}$ & $.057^{* * *}$ & $.051^{* * *}$ & $.057^{* * *}$ & -.013 & $.075^{* * *}$ \\
& $(.006)$ & $(.015)$ & $(.014)$ & $(.019)$ & $(.038)$ & $(.019)$ \\
Net debt & $-.006^{* * *}$ & $-.006^{* * *}$ & $-.006^{* * *}$ & $-.006^{* * *}$ & $-.012^{* * *}$ & .001 \\
& $(.001)$ & $(.001)$ & $(.001)$ & $(.001)$ & $(.002)$ & $(.002)$ \\
TFP & $.034^{* * *}$ & $.032^{* * *}$ & $.029^{* * *}$ & $.042^{* * *}$ & $.064^{* * *}$ & .011 \\
& $(.005)$ & $(.005)$ & $(.005)$ & $(.005)$ & $(.014)$ & $(.008)$ \\
\cline { 2 - 7 } Fixed effects: & & & & & & \\
Firm fixed-effects & Yes & Yes & Yes & Yes & Yes & Yes \\
Year dummies & No & Yes & Yes & Yes & Yes & Yes \\
Year×sector dummies & No & No & Yes & No & No & No \\
\cline { 2 - 8 } Observations & 696,889 & 696,889 & 696,889 & 565,848 & 124,394 & 260,317 \\
Adjusted $R^{2}$ & .18 & .18 & .18 & .16 & .15 & .20 \\
\hline \hline
\end{tabular}

Notes: $* * *$ pvalue $<0.01, * *$ pvalue $<0.05, *$ pvalue $<0.10$.

Robust standard errors in brackets.

Notes: The dependent variable is capital expenditure net of real estate acquisition normalized by the $P P E$ stock in year $t-1$. Column 1 is an OLS estimation of equation (19) without year dummies. Column 2 corresponds to the same equation with year dummies. Column 3 introduces also year $\times$ sector dummies. Column 4 reports the estimates of equation (19) for single-establishment firms. Columns 5 and 6 present the estimates of equation (19) for "small" and "large" firms, respectively. Sources: FiBEn. 
Table 4: Real estate holdings, prices and investment behavior - Heterogeneous effects by deciles of real estate holding

\begin{tabular}{|c|c|c|c|c|c|c|}
\hline & $(1)$ & $(2)$ & $(3)$ & (4) & $(5)$ & $(6)$ \\
\hline \multirow[t]{2}{*}{ NREH } & $.11^{* * *}$ & $.11^{* * *}$ & $.11^{* * *}$ & $.11^{* * *}$ & $.13^{* * *}$ & $.10^{* * *}$ \\
\hline & $(.005)$ & $(.005)$ & $(.005)$ & $(.005)$ & $(.012)$ & $(.007)$ \\
\hline \multirow{2}{*}{ Real estate prices } & $-.14^{* * *}$ & $-.048^{* * *}$ & $-.052^{* * *}$ & $-.073^{* * *}$ & $-.13^{* * *}$ & -.013 \\
\hline & $(.015)$ & $(.018)$ & $(.018)$ & $(.022)$ & $(.046)$ & $(.028)$ \\
\hline \multirow[t]{2}{*}{ Real estate prices $\times$ dec 2} & $.043^{* * *}$ & $.046^{* * *}$ & $.046^{* * *}$ & $.059 * * *$ & $.081^{* *}$ & .032 \\
\hline & $(.016)$ & $(.016)$ & $(.016)$ & $(.016)$ & $(.035)$ & $(.030)$ \\
\hline \multirow[t]{2}{*}{ Real estate prices $\times$ dec 3} & $.035^{* *}$ & $.04^{* *}$ & $.041^{* *}$ & $.051^{* * *}$ & .048 & .032 \\
\hline & $(.018)$ & $(.018)$ & $(.018)$ & $(.017)$ & $(.035)$ & $(.030)$ \\
\hline \multirow[t]{2}{*}{ Real estate prices $\times$ dec 4} & $.056^{* * *}$ & $.063^{* * *}$ & $.063^{* * *}$ & $.089 * * *$ & $.10^{* *}$ & $.053^{*}$ \\
\hline & $(.018)$ & $(.018)$ & $(.018)$ & $(.018)$ & $(.040)$ & $(.030)$ \\
\hline \multirow[t]{2}{*}{ Real estate prices $\times$ dec 5} & $.094^{* * *}$ & $.10^{* * *}$ & $.10^{* * *}$ & $.11^{* * *}$ & $.090^{* *}$ & $.091^{* * *}$ \\
\hline & $(.019)$ & $(.019)$ & $(.019)$ & $(.018)$ & $(.036)$ & $(.030)$ \\
\hline \multirow{2}{*}{ Real estate prices $\times \operatorname{dec} 6$} & $.12^{* * *}$ & $.13^{* * *}$ & $.13^{* * *}$ & $.14^{* * *}$ & $.14^{* * *}$ & $.096^{* * *}$ \\
\hline & $(.019)$ & $(.018)$ & $(.018)$ & $(.018)$ & $(.036)$ & $(.028)$ \\
\hline \multirow[t]{2}{*}{ Real estate prices $\times \operatorname{dec} 7$} & $.16^{* * *}$ & $.17^{* * *}$ & $.17^{* * *}$ & $.18^{* * *}$ & $.17^{* * *}$ & $.14^{* * *}$ \\
\hline & $(.020)$ & $(.020)$ & $(.020)$ & $(.019)$ & $(.037)$ & $(.028)$ \\
\hline \multirow[t]{2}{*}{ Real estate prices $\times \operatorname{dec} 8$} & $.19^{* * *}$ & $.21^{* * *}$ & $.20^{* * *}$ & $.22^{* * *}$ & $.25^{* * *}$ & $.15^{* * *}$ \\
\hline & $(.021)$ & $(.021)$ & $(.021)$ & $(.02)$ & $(.039)$ & $(.029)$ \\
\hline \multirow{2}{*}{ Real estate prices $\times \operatorname{dec} 9$} & $.25 * * *$ & $.27^{* * *}$ & $.27 * * *$ & $.27^{* * *}$ & $.31^{* * *}$ & $.23^{* * *}$ \\
\hline & $(.020)$ & $(.020)$ & $(.020)$ & $(.020)$ & $(.043)$ & $(.029)$ \\
\hline \multirow[t]{2}{*}{ Real estate prices $\times \operatorname{dec} 10$} & $.35^{* * *}$ & $.36^{* * *}$ & $.36^{* * *}$ & $.37 * * *$ & $.38^{* * *}$ & $.31^{* * *}$ \\
\hline & $(.023)$ & $(.023)$ & $(.023)$ & $(.023)$ & $(.051)$ & $(.033)$ \\
\hline \multirow{2}{*}{ Net debt } & $-.006 * * *$ & $-.006^{* * *}$ & $-.006^{* * *}$ & $-.006 * * *$ & $-.012^{* * *}$ & .001 \\
\hline & $(.001)$ & $(.001)$ & $(.001)$ & $(.001)$ & $(.003)$ & $(.002)$ \\
\hline \multirow[t]{2}{*}{$\mathrm{TFP}$} & $.032^{* * *}$ & $.034^{* * *}$ & $.032^{* * *}$ & $.043^{* * *}$ & $.063^{* * *}$ & $.014^{*}$ \\
\hline & $(.005)$ & $(.005)$ & $(.005)$ & $(.005)$ & $(.014)$ & $(.008)$ \\
\hline \multicolumn{7}{|l|}{ Fixed effects: } \\
\hline Decile dummies & Yes & Yes & Yes & Yes & Yes & Yes \\
\hline Firm fixed-effects & Yes & Yes & Yes & Yes & Yes & Yes \\
\hline Year dummies & No & Yes & Yes & Yes & Yes & Yes \\
\hline Year $\times$ sector dummies & No & No & Yes & No & No & No \\
\hline Observations & 696,599 & 696,599 & 696,599 & 565,612 & 124,344 & 260,218 \\
\hline Adjusted $R^{2}$ & .18 & .18 & .18 & .17 & .16 & .20 \\
\hline
\end{tabular}

Notes: $* * *$ pvalue $<0.01 . * *$ pvalue $<0.05 . *$ pvalue $<0.10$.

Robust standard errors in brackets.

Notes: The dependent variable is capital expenditure net of real estate acquisition normalized by the $P P E$ stock in year $t-1$. Column 1 is an OLS estimation of equation (20) without year dummies. Column 2 corresponds to the same equation with year dummies. Column 3 introduces also year $\times$ sector dummies. Column 4 reports the estimates of equation (20) for single-establishment firms. Columns 5 and 6 present the estimates of equation (20) for "small" and "large" firms, respectively. Sources: FiBEn. 
Column 1 reports OLS parameter estimates of equation (20) without year fixed effects. The coefficients associated with interactions between real estate prices and deciles of the sectoral $N R E H$ distribution exhibit a pattern which is very much in line with our theoretical results. We observe a monotonic increase in the estimated values, going from negative values for the lowest decile to high positive values for the highest ones. While the investment of firms that have few real estate holdings compared to their sectoral peers is slightly negatively affected by an increase in real estate prices, the investment of those holding more real estate, relatively to their peers, is very significantly and positively impacted by increasing real estate prices. Estimated values of the coefficient associated with the other regressors remain largely unaffected by the introduction of interactions between real estate prices and NREH deciles into the list of regressors. Column 2 corresponds to the same estimation with year fixed effects. In column 3 , we add year $\times$ sector fixed effects. Parameter estimates are similar for these three specifications. Results from our preferred estimation (column 2) imply that a $10 \%$ increase in real estate prices causes a 0.48 percentage point decrease in the investment rate of firms belonging to the first decile of the $N R E H$ distribution, that is to say approximately $1 \%$ of the mean investment rate in the first $N R E H$ decile, but a 3.1 percentage point increase in the investment rate of firms belonging to the last decile, that is to say approximately $6 \%$ of the mean investment rate in the top $N R E H$ decile. In column 4 , we present estimated parameters of equation (20) for single-establishment firms only. Estimates are similar to those obtained for the whole sample (column 2, Table 4) except for the estimated parameter associated with the interaction terms between real estate prices and the lowest NREH deciles. These results echo estimates reported in columns 5 and 6 which present estimates of the same equation for small and large firms, respectively. The negative effect of real estate price increases on the investment rate of firms located in the first deciles of the NREH distribution is much higher for small firms than for large firms. This could result from differences in the intensity of the borrowing constraint of small and large firms. Moreover, there may be concern that the increase in the estimated coefficients associated with the interaction terms could result from the variability of firms' size across deciles. The fact that we find the same patterns of results for both sub-samples (namely, small and large firms) gives credence to the idea that it is mainly the intensity in real estate holding, namely the $N R E H$ value, that matters for predicting the effect of real estate prices on firms' productive investment.

Let us examine now the effect of real estate prices on the productive investment of non-real estate-holding firms.

We first estimate equation (19) on the sub-sample of firm $\times$ year observations for which no real estate asset is reported (column 1, Table 5). Real estate prices are found to be slightly positively correlated with corporate investment but the estimate is not statistically significant. Estimated coefficients associated with net debt and total factor productivity are similar to the ones found for the whole sample and both statistically significant at the 1 percent level. We study further the effect of real estate prices on non-real estate-holding firms by splitting the firm $\times$ year observations into three categories:

- firms that have never reported real estate assets over the observation period $(82,599$ firms and 634,765 firm $\times$ year observations),

- firms that do not report real estate assets in the current period but had reported real estate assets before (6,637 firms and 37,160 firm $\times$ year observations), 
Table 5: Real estate prices and investment behavior - Results no real estate firms

\begin{tabular}{lccccc}
\hline \hline & $(1)$ & $(2)$ & $(3)$ & $(4)$ & $(5)$ \\
\hline Real estate prices & .012 & .031 & .001 & $-.18^{*}$ & $-.54^{*}$ \\
& $(.023)$ & $(.025)$ & $(.09)$ & $(.11)$ & $(.31)$ \\
Net debt & $-.006^{* * *}$ & $-.006^{* * *}$ & $-.013^{* * *}$ & $-.010^{* *}$ & $-.021^{* * *}$ \\
& $(.001)$ & $(.001)$ & $(.003)$ & $(.004)$ & $(.008)$ \\
TFP & $.067^{* * *}$ & $.064^{* * *}$ & $.094^{* * *}$ & $.053^{*}$ & $.17^{* * *}$ \\
& $(.008)$ & $(.008)$ & $(.035)$ & $(.029)$ & $(.064)$ \\
\cline { 2 - 6 } Fixed effects: & & & & & \\
Firm fixed-effects & Yes & Yes & Yes & Yes & Yes \\
Year dummies & Yes & Yes & Yes & Yes & Yes \\
\cline { 2 - 6 } Observations & 750,410 & 634,765 & 37,160 & 73,259 & 37,351 \\
Adjusted $R^{2}$ & .15 & .14 & .18 & .20 & .18 \\
\hline \hline
\end{tabular}

Notes: $* * *$ pvalue $<0.01 . * *$ pvalue $<0.05 . *$ pvalue $<0.10$.

Robust standard errors in brackets.

Notes: The dependent variable is capital expenditure net of real estate acquisition normalized by the $P P E$ stock in year $t-1$. Column 1 reports estimates from the sample made of firm $\times$ year observations for which no real estate assets are reported. Column 2 corresponds to the same estimation on the sub-sample made of firms that have never held real estate. Column 3 and 4 correspond to firms that don't report real estate assets in contemporaneous period but have reported real estate before (column 3) or after (column 4). In column 5, we restrict the analysis to the 3 years preceding the acquisition. Sources: FiBEn. 
- firms that do not report real estate assets in the current period but will acquire real estate assets afterward (15,598 firms and 73,259 firm $\times$ year observations).

Results are presented in columns 2, 3 and 4 of Table 5 , respectively. We observe that real estate prices do not significantly affect productive investment of the first two categories but have a negative impact, statistically significant at the 10 percent level, on the last category. This negative effect of real estate prices on firms' investment is more pronounced if we restrict the analysis to the three years preceding real estate acquisition (column 5, Table 5). These results tend to show that non-real estate-holding firms are rather immune from real estate prices when they are not considering real estate acquisitions. The negative effect of an increase in real estate prices on capital investment could result from a crowding-out effect of planned real estate investment on current productive investments. These results can be alternatively explained by the above-mentioned measurement issue. More precisely, firms that initially report no real estate holdings and that, at some point in time, start reporting real estate assets on their balance sheet are unlikely to be involved in the legal separation of real estate holdings prior to the acquisition. Hence, even if the legal separation of real estate holdings blurs the effects of real estate prices for seemingly non-real estate-holding firms, we nevertheless expect that real estate prices have a negative impact on the investment of firms that report no real estate assets in the current period but acquire some later.

\subsection{Complementary robustness checks}

We have identified varying effects of real estate prices on corporate investment depending on the position of the firms in the NREH sectoral distributions. However, these results could be biased if real estate holdings were correlated with the sensitivity of investment to local real estate prices. For example, we would overestimate the effect of real estate prices on investment for real estate-rich firm if those firms were more sensitive to the local economic condition. This issue of the sensitivity to local economic condition is partly addressed by the consideration of sectoral distributions for the variable $N R E H$. Nevertheless, we can refine our analysis by introducing interaction terms between real estate prices and age, size or profit margin of the firm in equation (20). Indeed, if age, size or profitability are correlated with firms' real estate holdings as well as with firms' sensitivity to local economic conditions, the introduction of those interaction terms is required to properly identify the impact of real estate prices. The estimation results corresponding to this specification are presented in column 2 in Table 6 whereas column 1 reports our baseline estimates presented in column 2 in Table 20. Our results are largely unaffected by the introduction of these interactions terms.

Another possible cause for concern could be that firms invest in real estate asset prior to investing in productive assets entailing a spurious correlation, possibly varying with the level of real estate prices, between real estate holdings and subsequent productive investment. In order to ensure that this mechanism doesn't affect our results, we present estimation results of equation (20) with lagged values for real estate holdings ( 3 and 4 years, respectively) in column 2 and 3 in Table 6 . These alternative specifications tend to alter the precision of our estimates associated with interacted prices even if we still obtain the same upward trend.

As mentioned above, real estate prices are likely to be correlated with local investment opportunities. Our empirical strategy relies on the comparison of the investment of firms facing the same local economic conditions but varying exposition to real estate prices because of different real estate holdings. The efficiency of this difference-in-difference strategy 
in disentangling the effects of real estate prices on investment from the impact of local economic impetus can be assessed by stratifying firms belonging to tradable and non-tradable sectors. Indeed, firms operating in tradable sectors are less affected by local economic condition while they are similarly affected by the profit and the collateral channels following real estate prices' fluctuations. The estimation results of equation (20) for firms operating in tradable sectors are presented in column 4 of Table 6 , results for firms operating in non-tradable sectors are presented in column 5. The sign and the magnitude of the estimates associated with prices are similar in the two sub-samples. We also would like to account for other local economic variables likely to affect corporate investment and to correlate with real estate prices. Local unemployment rate at the département's level are produced by the INSEE for the whole period studied. We estimate equation (20) adding a variable corresponding to the local unemployment rate in the département where the firm $i$ is headquartered in year $t$. The results are reported in column 7 in Table 6 . We obtain an expected negative and statistically significant estimate for the coefficient associated with the local unemployment. The other estimates are not altered by the introduction of this control. ${ }^{27}$

We do not tackle the issue of attrition because we do not have precise information on the reasons why firms enter or exit the sample. Nevertheless, to ensure that the moves in and out of the sample do not affect our results, we estimate our preferred equation (column 1, Table 7), on a balanced panel in which firms are observed each year from 1994 onwards. Results are reported in column 2, Table 7. Our findings concerning the impact of prices are robust to this restriction. In columns 3 and 4 , we present the results of our baseline estimation conducted on two subperiods of equal length, 1994-2003 and 2004-2013, respectively. The estimate associated with the $N R E H$ variable increases during the second half of the observation period, which suggests that firms may have faced fiercer credit constraint during this subperiod. Columns 5 and 6 report the results obtained when the amortization rate used to build $N R E H$ series is $3 \%$ and $5 \%$ per year, respectively, instead of $4 \%$ per year in our baseline estimation. The estimates are unaffected, except for the coefficient associated with the NREH variable. This coefficient mechanically increases with the depreciation rate as, in a context of an overall sharp increase in real estate prices, the older the acquisition date the higher the proxied real estate volume. Column 7 corresponds to the subsample without firms headquartered in Ile-de-France (Paris region) which appears to be an outlier with respect to real estate prices evolution (see Figure 2 in Appendix C). Column 8 shows that considering an alternative measure of TFP, that is to say residuals from simple OLS regression at 2-digit level, has no impact on our results.

\subsection{The borrowing capacity channel and other real effects of real estate prices}

In our model, the effect of real estate prices on productive investment of constrained firms is channeled through changes in the firms' borrowing capacity; for unconstrained firms, real estate prices may also affect (negatively) the level of debt if investment is not internally financed. Hence, we should observe similar results with regards to the impact of the different explanatory variables on investment and on new bank loans. Unfortunately, the balance sheet data do not provide information on the new bank loans. We only observe the amount

\footnotetext{
${ }^{27}$ In unreported regressions, we find that when we interact local unemployment with the $N R E H$ deciles, none of the coefficient associated with the interacted terms is statistically significant.
} 
Table 6: Real estate holdings, prices and investment behavior - Robustness checks I

\begin{tabular}{|c|c|c|c|c|c|c|c|}
\hline & (1) & $(2)$ & (3) & (4) & $(5)$ & $(6)$ & (7) \\
\hline NREH & $\begin{array}{l}.11^{* * * *} \\
(.005)\end{array}$ & $\begin{array}{l}.11^{* * * *} \\
(.005)\end{array}$ & $\begin{array}{c}.028^{* * *} \\
(.004)\end{array}$ & $\begin{array}{l}.012^{* *} \\
(.005)\end{array}$ & $\begin{array}{l}.09 * * * \\
(.005)\end{array}$ & $\begin{array}{l}.12^{* * * *} \\
(.006)\end{array}$ & $\begin{array}{l}.11^{* * * *} \\
(.005)\end{array}$ \\
\hline Real estate prices & $\begin{array}{c}-.048^{* * *} \\
(.018)\end{array}$ & $\begin{array}{c}-.14^{* * *} \\
(.019)\end{array}$ & $\begin{array}{l}-.026 \\
(.020)\end{array}$ & $\begin{array}{l}-.016 \\
(.023)\end{array}$ & $\begin{array}{c}-.054^{* *} \\
(.026)\end{array}$ & $\begin{array}{l}-.035 \\
(.025)\end{array}$ & $\begin{array}{c}-.056^{* * *} \\
(.019)\end{array}$ \\
\hline Real estate prices $\times$ dec 2 & $\begin{array}{c}.046^{* * *} \\
(.016)\end{array}$ & $\begin{array}{c}.041^{* * *} \\
(.008)\end{array}$ & $\begin{array}{c}.007 \\
(.016)\end{array}$ & $\begin{array}{l}-.006 \\
(.017)\end{array}$ & $\begin{array}{l}.051^{* *} \\
(.023)\end{array}$ & $\begin{array}{l}.037^{*} \\
(.019)\end{array}$ & $\begin{array}{c}.046^{* * *} \\
(.016)\end{array}$ \\
\hline Real estate prices $\times$ dec 3 & $\begin{array}{l}.04^{* *} \\
(.018)\end{array}$ & $\begin{array}{l}.031^{*} \\
(.018)\end{array}$ & $\begin{array}{l}.009 \\
(.016)\end{array}$ & $\begin{array}{l}.013 \\
(.017)\end{array}$ & $\begin{array}{c}.037 \\
(.023)\end{array}$ & $\begin{array}{c}.034 \\
(.022)\end{array}$ & $\begin{array}{l}.039^{* *} \\
(.018)\end{array}$ \\
\hline Real estate prices $\times \operatorname{dec} 4$ & $\begin{array}{c}.063^{* * *} \\
(.018)\end{array}$ & $\begin{array}{c}.050^{* * * *} \\
.018)\end{array}$ & $\begin{array}{l}.020 \\
(.017)\end{array}$ & $\begin{array}{l}.015 \\
(.018)\end{array}$ & $\begin{array}{l}.039^{*} \\
(.023)\end{array}$ & $\begin{array}{c}.065^{* * *} \\
(.024)\end{array}$ & $\begin{array}{c}.063^{* * * *} \\
(.018)\end{array}$ \\
\hline Real estate prices $\times$ dec 5 & $\begin{array}{l}.10^{* * * *} \\
(.019)\end{array}$ & $\begin{array}{c}.086^{* * * *} \\
(.019)\end{array}$ & $\begin{array}{c}.052^{* * *} \\
(.017)\end{array}$ & $\begin{array}{l}.030^{*} \\
(.017)\end{array}$ & $\begin{array}{c}.067^{* * *} \\
(.023)\end{array}$ & $\begin{array}{l}.11^{* * *} \\
(.026)\end{array}$ & $\begin{array}{l}.10^{* * * *} \\
(.019)\end{array}$ \\
\hline Real estate prices $\times$ dec 6 & $\begin{array}{l}.13^{* * *} \\
(.018)\end{array}$ & $\begin{array}{l}.11^{* * *} \\
(.019)\end{array}$ & $\begin{array}{c}.081^{* * *} \\
(.018)\end{array}$ & $\begin{array}{c}.049 * * * \\
(.018)\end{array}$ & $\begin{array}{c}.099 * * * \\
(.021)\end{array}$ & $\begin{array}{l}.13^{* * *} \\
(.025)\end{array}$ & $\begin{array}{l}.13^{* * *} \\
(.018)\end{array}$ \\
\hline Real estate prices $\times \operatorname{dec} 7$ & $\begin{array}{l}.17^{* * * *} \\
(.020)\end{array}$ & $\begin{array}{l}.15^{* * *} \\
(.020)\end{array}$ & $\begin{array}{c}.085^{* * *} \\
(.017)\end{array}$ & $\begin{array}{c}.089^{* * *} \\
(.017)\end{array}$ & $\begin{array}{l}.15^{* * *} \\
(.022)\end{array}$ & $\begin{array}{l}.17^{* * *} \\
(.028)\end{array}$ & $\begin{array}{l}.17^{* * * *} \\
(.020)\end{array}$ \\
\hline Real estate prices $\times$ dec 8 & $\begin{array}{l}.21^{* * *} \\
(.021)\end{array}$ & $\begin{array}{l}.18^{* * * *} \\
(.021)\end{array}$ & $\begin{array}{l}.12^{* * * *} \\
(.018)\end{array}$ & $\begin{array}{l}.10^{* * *} \\
(.018)\end{array}$ & $\begin{array}{l}.18^{* * *} \\
(.022)\end{array}$ & $\begin{array}{l}.20^{* * *} \\
(.029)\end{array}$ & $\begin{array}{l}.21^{* * *} \\
(.021)\end{array}$ \\
\hline Real estate prices $\times$ dec 9 & $\begin{array}{l}.27^{* * *} \\
(.020)\end{array}$ & $\begin{array}{l}.24^{* * *} \\
(.020)\end{array}$ & $\begin{array}{l}.19^{* * *} \\
(.019)\end{array}$ & $\begin{array}{l}.13^{* * *} \\
(.019)\end{array}$ & $\begin{array}{l}.22^{* * *} \\
(.024)\end{array}$ & $\begin{array}{l}.27^{* * *} \\
(.027)\end{array}$ & $\begin{array}{l}.27^{* * *} \\
(.020)\end{array}$ \\
\hline Real estate prices $\times \operatorname{dec} 10$ & $\begin{array}{l}.36^{* * *} \\
(.023)\end{array}$ & $\begin{array}{l}.33^{* * *} * \\
(.024)\end{array}$ & $\begin{array}{l}.21^{* * *} \\
(.020)\end{array}$ & $\begin{array}{l}.15^{* * *} \\
(.023)\end{array}$ & $\begin{array}{l}.28^{* * *} \\
(.029)\end{array}$ & $\begin{array}{l}.37 * * * \\
(.030)\end{array}$ & $\begin{array}{l}.36^{* * * *} \\
(.023)\end{array}$ \\
\hline Net debt & $\begin{array}{c}-.006^{* * *} \\
(.001)\end{array}$ & $\begin{array}{c}-.006^{* * *} \\
(.001)\end{array}$ & $\begin{array}{c}-.007 * * * \\
(.001)\end{array}$ & $\begin{array}{c}-.010^{* * *} \\
(.001)\end{array}$ & $\begin{array}{c}-.005^{* *} \\
(.002)\end{array}$ & $\begin{array}{c}-.006^{* * *} \\
(.001)\end{array}$ & $\begin{array}{c}-.006^{* * *} \\
(.001)\end{array}$ \\
\hline TFP & $\begin{array}{c}.034^{* * *} \\
(.005)\end{array}$ & $\begin{array}{c}.036^{* * *} \\
(.005)\end{array}$ & $\begin{array}{c}.043^{* * *} \\
(.006)\end{array}$ & $\begin{array}{c}.036^{* * *} \\
(.008)\end{array}$ & $\begin{array}{l}.10^{* * *} \\
(.008)\end{array}$ & $\begin{array}{l}.001 \\
(.007)\end{array}$ & $\begin{array}{c}.034^{* * *} \\
(.005)\end{array}$ \\
\hline Unemployment rate & & & & & & & $\begin{array}{c}-.0077^{* * *} \\
(.0027)\end{array}$ \\
\hline Real estate prices $\times$ (age, size, profit $)$ & No & Yes & No & No & No & No & No \\
\hline Fixed effects: & & & & & & & \\
\hline $\mathrm{De}$ & Yes & Yes & Yes & Yes & $\mathrm{Ye}$ & Yes & Yes \\
\hline Firm fixed-effects & Yes & Yes & Yes & Yes & Yes & Yes & Yes \\
\hline Year dummies & Yes & Yes & Yes & Yes & Yes & Yes & Yes \\
\hline Obse & 696,599 & 693,734 & 567,189 & 499,283 & 253,635 & 442,964 & 696,599 \\
\hline Adjusted $R^{2}$ & .18 & .18 & .17 & .17 & .15 & .19 & .18 \\
\hline
\end{tabular}

Notes: $* * *$ pvalue $<0.01 . * *$ pvalue $<0.05 . *$ pvalue $<0.10$.

Robust standard errors in brackets.

Notes: The dependent variable is capital expenditure net of real estate acquisition normalized by the $P P E$ stock in year $t-1$. Column 1 is our benchmark result; that is to say column 2 in Table 4 . Column 2 is an OLS estimation of equation (20) where we add interaction terms between real estate prices and the firm's age, the size of the balance sheet and the profit margin. Column 3 and 4 present estimation results of equation (20) with lagged values for real estate holdings ( 3 and 4 years, respectively). Column 5 reports the estimates of equation (20) for firms operating in tradable sectors (manufacturing sectors) whereas column 6 reports results for firms operating in non-tradable sectors (non-manufacturing sectors). Column 7 presents results of equation (20) when we control for the unemployment rate at the département's level. Sources: FiBEn. 
Table 7: Real estate holdings, prices and investment behavior - Robustness checks II

\begin{tabular}{|c|c|c|c|c|c|c|c|c|}
\hline & $(1)$ & $(2)$ & (3) & $(4)$ & $(5)$ & $(6)$ & (7) & (8) \\
\hline \multirow[t]{2}{*}{ NREH } & $.11^{* * *}$ & $.11^{* * *}$ & $.10^{* * *}$ & $.18^{* * *}$ & $.057^{* * *}$ & $.16^{* * *}$ & $.11^{* * *}$ & $.11^{* * *}$ \\
\hline & $(.005)$ & $(.008)$ & $(.008)$ & $(.008)$ & $(.003)$ & $(.006)$ & $(.005)$ & $(.005)$ \\
\hline \multirow[t]{2}{*}{ Real estate prices } & $-.048^{* * *}$ & $-.052^{*}$ & -.002 & $-.11^{* * *}$ & $-.050 * * *$ & $-.044^{* * *}$ & $-.094^{* * *}$ & $-.047^{* * *}$ \\
\hline & $(.018)$ & $(.028)$ & $(.035)$ & $(.035)$ & $(.018)$ & $(.019)$ & $(.022)$ & $(.016)$ \\
\hline \multirow[t]{2}{*}{ Real estate prices $\times \operatorname{dec} 2$} & $.046^{* * *}$ & .019 & .024 & $.047^{*}$ & $.041^{* * *}$ & $.048^{* * *}$ & .028 & $.046^{* * *}$ \\
\hline & $(.016)$ & $(.026)$ & $(.032)$ & $(.028)$ & $(.015)$ & $(.017)$ & $(.018)$ & $(.016)$ \\
\hline \multirow[t]{2}{*}{ Real estate prices $\times$ dec 3} & $.04^{* *}$ & .015 & .011 & .051 & $.032^{* *}$ & $.041^{* *}$ & .021 & $.04^{* *}$ \\
\hline & $(.018)$ & $(.028)$ & $(.037)$ & $(.035)$ & $(.016)$ & $(.017)$ & $(.019)$ & $(.018)$ \\
\hline \multirow[t]{2}{*}{ Real estate prices $\times$ dec 4} & $.063^{* * *}$ & .011 & $.059^{*}$ & $.093^{* *}$ & $.057^{* * *}$ & $.073^{* * *}$ & .031 & $.062^{* * *}$ \\
\hline & $(.018)$ & $(.025)$ & $(.035)$ & $(.036)$ & $(.018)$ & $(.018)$ & $(.020)$ & $(.018)$ \\
\hline \multirow[t]{2}{*}{ Real estate prices $\times \operatorname{dec} 5$} & $.10^{* * *}$ & $.058^{* *}$ & $.078^{* *}$ & $.17^{* * *}$ & $.093^{* * *}$ & $.089^{* * *}$ & $.059^{* * *}$ & $.10^{* * *}$ \\
\hline & $(.019)$ & $(.024)$ & $(.036)$ & $(.038)$ & $(.018)$ & $(.018)$ & $(.019)$ & $(.019)$ \\
\hline \multirow[t]{2}{*}{ Real estate prices $\times$ dec 6} & $.13^{* * *}$ & $.039^{*}$ & $.13^{* *}$ & $.15^{* * *}$ & $.11 * * *$ & $.14^{* * *}$ & $.11^{* * *}$ & $.13^{* * *}$ \\
\hline & $(.018)$ & $(.022)$ & $(.038)$ & $(.040)$ & $(.020)$ & $(.018)$ & $(.020)$ & $(.018)$ \\
\hline \multirow[t]{2}{*}{ Real estate prices $\times$ dec 7} & $.17^{* * *}$ & $.10^{* * *}$ & $.18^{* * *}$ & $.22^{* * *}$ & $.16^{* * *}$ & $.17^{* * *}$ & $.14^{* * *}$ & $.17^{* * *}$ \\
\hline & $(.020)$ & $(.023)$ & $(.041)$ & $(.042)$ & $(.019)$ & $(.020)$ & $(.019)$ & $(.020)$ \\
\hline \multirow[t]{2}{*}{ Real estate prices $\times \operatorname{dec} 8$} & $.21^{* * *}$ & $.11^{* * *}$ & $.23^{* * *}$ & $.25^{* * *}$ & $.19^{* * *}$ & $.21^{* * *}$ & $.18^{* * *}$ & $.21^{* * *}$ \\
\hline & $(.021)$ & $(.024)$ & $(.043)$ & $(.048)$ & $(.020)$ & $(.023)$ & $(.020)$ & $(.021)$ \\
\hline \multirow[t]{2}{*}{ Real estate prices $\times \operatorname{dec} 9$} & $.27^{* * *}$ & $.18^{* * *}$ & $.29^{* * *}$ & $.28^{* * *}$ & $.26^{* * *}$ & $.26^{* * *}$ & $.26^{* * *}$ & $.27^{* * *}$ \\
\hline & $(.020)$ & $(.023)$ & $(.045)$ & $(.076)$ & $(.020)$ & $(.020)$ & $(.021)$ & $(.020)$ \\
\hline \multirow[t]{2}{*}{ Real estate prices $\times$ dec 10} & $.36^{* * *}$ & $.29^{* * *}$ & $.34^{* * *}$ & $.37^{* * *}$ & $.36^{* * *}$ & $.35^{* * *}$ & $.36^{* * *}$ & $.36^{* * *}$ \\
\hline & $(.023)$ & $(.029)$ & $(.052)$ & $(.051)$ & $(.022)$ & $(.024)$ & $(.025)$ & $(.023)$ \\
\hline \multirow[t]{2}{*}{ Net Debt } & $-.006^{* * *}$ & $-.010 * * *$ & -.002 & $-.011^{* * *}$ & $-.006^{* * *}$ & $-.006^{* * *}$ & $-.006^{* * *}$ & $-.005^{* * *}$ \\
\hline & $(.001)$ & $(.002)$ & $(.003)$ & $(.002)$ & $(.001)$ & $(.001)$ & $(.001)$ & $(.001)$ \\
\hline \multirow[t]{2}{*}{$\mathrm{TFP}$} & $.034^{* * *}$ & $.054^{* * *}$ & $.026^{* * *}$ & $.025^{* * *}$ & $.035^{* * *}$ & $.034^{* * *}$ & $.038^{* * *}$ & $.15^{* * *}$ \\
\hline & $(.005)$ & $(.009)$ & $(.007)$ & $(.008)$ & $(.005)$ & $(.005)$ & $(.005)$ & $(.005)$ \\
\hline \multicolumn{9}{|l|}{ Fixed effects: } \\
\hline Decile dummies & Yes & Yes & Yes & Yes & Yes & Yes & Yes & Yes \\
\hline Firm fixed-effects & Yes & Yes & Yes & Yes & Yes & Yes & Yes & Yes \\
\hline Year dummies & Yes & Yes & Yes & Yes & Yes & Yes & Yes & Yes \\
\hline Observations & 696,599 & 207,692 & 300,284 & 396,315 & 697,243 & 696,599 & 586,863 & 696,599 \\
\hline Adjusted $R^{2}$ & .18 & .14 & .19 & .21 & .18 & .18 & .17 & .18 \\
\hline
\end{tabular}

Notes: $* * *$ pvalue $<0.01 . * *$ pvalue $<0.05 . *$ pvalue $<0.10$.

Robust standard errors in brackets.

Notes: The dependent variable is capital expenditure net of real estate acquisition normalized by the $P P E$ stock in year $t-1$. Column 1 is our benchmark result; that is the column 2 in Table 4 . Column 2 reports the estimation of equation (20) on a balanced panel where all the firms are observed from the year 1994 onwards. Columns 3 and 4 present the estimates of the same equation on two sub-periods : 1994-2003 and 2004-2013, respectively. Column 5 and 6 report the results obtained when the amortization rate retained to build the $N R E H$ variable is, respectively, $3 \%$ and $5 \%$ per year, vs $4 \%$ in baseline estimate. Column 7 corresponds to a sample where the firms headquartered in the Paris area are not taken into account. Column 8 uses an alternative measure of TFP, that is to say residuals from simple OLS regression at 2-digit level. Sources: FiBEn. 
of outstanding bank loans at each period. The variation in this amount results from new loans as well as debt repayments. As we can not disentangle those two components, we consider the positive variation in the amount of outstanding loan as a proxy for new loans. We estimate the following equation:

$$
\begin{aligned}
\Delta \text { Debt }_{i t} & =\alpha_{i}+\gamma_{t}+\beta_{1} N R E H_{i t-1}^{d}+\sum_{j=1}^{10} \beta_{2}^{j} D_{i t-1}^{j} \text { Price }_{t}^{d}+\sum_{j=1}^{10} \lambda_{j} D_{i t-1}^{j} \\
& +\beta_{3} \text { NetDebt } i t-1+\beta_{4} T F P_{i t-1}+\epsilon_{i t}
\end{aligned}
$$

where $\Delta$ Debt $_{i t}$ is the difference between the outstanding bank loans in period $t$ and the outstanding bank loans in period $t-1$ if this difference is positive and 0 otherwise normalized by the PPE stock in period $t-1$.

We report the results of the estimation of equation (21) in the first column of Table 8. The estimates of the coefficients associated with interacted real estate prices present a pattern similar to the one obtained for the investment equation even though the effects in the last deciles are slightly lower. With the exception of net debt and TFP, for which we obtain non significant estimates, the signs of the estimates are in line with the theory and with the results obtained for the investment equations. This result tends to validate the idea that real estate prices affect investment through their effect on firms's borrowing capacity.

The data available also allows to explore the impact of real estate price on real estate investment and employment. We estimate equation (21) successively replacing the dependant variable $\Delta D_{e b t_{i t}}$ by the real estate investment $R E i n v_{i t}$, that we proxy by the positive variation in the gross value of real estate assets, and the employment variation $\Delta E m p_{i t}$, that is the percentage change in the FTE workforce in period $t$. The results are reported in the second and the third columns of Table 8. The estimates obtained when real estate investment is the dependent variable markedly differs from the ones obtained with productive investment. Although the estimates associated with NREH, Net Debt and TFP have the same signs, these last two are not statistically significant, the estimates associated with interacted real estate prices present a U-shaped pattern. The positive impact of prices on real estate investment for the first and the two last deciles are not statistically significant but the negative impact is statistically significant between the third decile and the seventh decile. This result suggests that the demand for real estate assets of firms holding few real estate assets is less price sensitive. The results on employment growth are in line with the ones obtained for productive investment.

We find that the employment growth of firms located in the first decile of the $N R E H$ distribution is reduced by 0.16 percentage point following a $10 \%$ increase in real estate prices whereas this growth rate is increased by 0.08 percentage point for firms located in the last decile following the same increase. It is noticeable that the negative impact of a price increase on employment growth is observed over a larger share of the $N R E H$ distribution (up to the eighth decile) than when the dependent variable is investment.

\subsection{Comparison to the existing literature}

The existing empirical literature on the real estate collateral channel has highlighted the amount of additional investment resulting from a 1 euro increase in the value of real estate holdings. This parameter cannot be easily recovered from the above-presented parameter estimates because of our estimation strategy aiming at disentangling the collateral channel 
Table 8: Real estate holdings, prices and other real effects

\begin{tabular}{|c|c|c|c|}
\hline & (1) & $(2)$ & $(3)$ \\
\hline NREH & $\begin{array}{c}.063^{* * *} \\
(.005)\end{array}$ & $\begin{array}{c}.024^{* * *} \\
(.003)\end{array}$ & $\begin{array}{c}.0024^{* * *} \\
(.0007)\end{array}$ \\
\hline Real estate prices & $\begin{array}{c}-.041^{* * *} \\
(.015)\end{array}$ & $\begin{array}{l}.013 \\
(.011)\end{array}$ & $\begin{array}{c}-.016^{* * *} \\
(.005)\end{array}$ \\
\hline Real estate prices $\times \operatorname{dec} 2$ & $\begin{array}{l}.013 \\
(.015)\end{array}$ & $\begin{array}{l}-.017 \\
(.009)\end{array}$ & $\begin{array}{l}.0006 \\
(.003)\end{array}$ \\
\hline Real estate prices $\times \operatorname{dec} 3$ & $\begin{array}{l}.003 \\
(.017)\end{array}$ & $\begin{array}{c}-.036^{* * *} \\
(.010)\end{array}$ & $\begin{array}{l}.005 \\
(.004)\end{array}$ \\
\hline Real estate prices $\times \operatorname{dec} 4$ & $\begin{array}{l}.012 \\
(.017)\end{array}$ & $\begin{array}{c}-.045^{* * *} \\
(.012)\end{array}$ & $\begin{array}{l}.002 \\
(.04)\end{array}$ \\
\hline Real estate prices $\times$ dec 5 & $\begin{array}{l}.038^{* *} \\
(.017)\end{array}$ & $\begin{array}{c}-.039^{* * *} \\
(.011)\end{array}$ & $\begin{array}{l}.006^{*} \\
(.004)\end{array}$ \\
\hline Real estate prices $\times$ dec 6 & $\begin{array}{c}.057^{* * * *} \\
(.017)\end{array}$ & $\begin{array}{c}-.031^{* * *} \\
(.011)\end{array}$ & $\begin{array}{l}.007^{*} \\
(.004)\end{array}$ \\
\hline Real estate prices $\times \operatorname{dec} 7$ & $\begin{array}{c}.071^{* * *} \\
(.017)\end{array}$ & $\begin{array}{c}-.023^{* *} \\
(.011)\end{array}$ & $\begin{array}{c}.011^{* * *} \\
(.004)\end{array}$ \\
\hline Real estate prices $\times \operatorname{dec} 8$ & $\begin{array}{l}.10^{* * *} \\
(.019)\end{array}$ & $\begin{array}{l}-.013 \\
(.011)\end{array}$ & $\begin{array}{c}.014^{* * *} \\
(.004)\end{array}$ \\
\hline Real estate prices $\times \operatorname{dec} 9$ & $\begin{array}{l}.12^{* * * *} \\
(.023)\end{array}$ & $\begin{array}{l}.009 \\
(.020)\end{array}$ & $\begin{array}{c}.017^{* * *} \\
(.006)\end{array}$ \\
\hline Real estate prices $\times \operatorname{dec} 10$ & $\begin{array}{l}.18^{* * * *} \\
(.028)\end{array}$ & $\begin{array}{l}.021 \\
(.014)\end{array}$ & $\begin{array}{c}.025^{* * *} \\
(.004)\end{array}$ \\
\hline Net debt & $\begin{array}{l}.0004 \\
(.002)\end{array}$ & $\begin{array}{r}-.0006 \\
(.001)\end{array}$ & $\begin{array}{l}-.0002 \\
(.0001)\end{array}$ \\
\hline $\mathrm{TFP}$ & $\begin{array}{l}-.0005 \\
(.005)\end{array}$ & $\begin{array}{l}.003 \\
(.004)\end{array}$ & $\begin{array}{c}.063^{* * *} \\
(.005)\end{array}$ \\
\hline Fixed effects: & & & \\
\hline $\begin{array}{l}\text { Decile dummies } \\
\text { Firm fixed-effects } \\
\text { Year dummies }\end{array}$ & $\begin{array}{l}\text { Yes } \\
\text { Yes } \\
\text { Yes }\end{array}$ & $\begin{array}{l}\text { Yes } \\
\text { Yes } \\
\text { Yes }\end{array}$ & $\begin{array}{l}\text { Yes } \\
\text { Yes } \\
\text { Yes }\end{array}$ \\
\hline Observations & 711,325 & 711,325 & 711,325 \\
\hline Adjusted $R^{2}$ & .16 & .02 & .03 \\
\hline
\end{tabular}

Notes: $* * *$ pvalue $<0.01 . * *$ pvalue $<0.05 . *$ pvalue $<0.10$.

Robust standard errors in brackets.

Notes: In column 1, the dependent variable is the difference between the outstanding bank loans in period $t$ and the outstanding bank loans in period $t-1$ normalized by the $P P E$ stock in period $t-1$. In column 2 , it is the difference between the the gross value of real estate assets in period $t$ and the the gross value of real estate assets in period $t-1$ normalized by the PPE stock in period $t-1$ and column 3 is the percentage change in the FTE workforce in period $t$. Sources: FiBEn. 
Table 9: Collateral value and investment behavior

\begin{tabular}{lcccccc}
\hline \hline & $(1)$ & $(2)$ & $(3)$ & $(4)$ & $(5)$ & $(6)$ \\
\hline REvalue & $.065^{* * *}$ & $.066^{* * *}$ & $.066^{* * *}$ & $.065^{* * *}$ & $.081^{* * *}$ & $.058^{* * *}$ \\
& $(.002)$ & $(.002)$ & $(.004)$ & $(.002)$ & $(.005)$ & $(.003)$ \\
Real estate prices & $-.041^{* * *}$ & -.021 & $-.030^{* *}$ & -.022 & $-.071^{* *}$ & .023 \\
& $(.007)$ & $(.015)$ & $(.014)$ & $(.018)$ & $(.029)$ & $(.020)$ \\
Net debt & $-.006^{* * *}$ & $-.006^{* * *}$ & $-.005^{* * *}$ & $-.005^{* * *}$ & $-.006^{* * *}$ & $-.002^{* *}$ \\
& $(.001)$ & $(.001)$ & $(.001)$ & $(.001)$ & $(.001)$ & $(.001)$ \\
TFP & $.041^{* * *}$ & $.039^{* * *}$ & $.036^{* * *}$ & $.044^{* * *}$ & $.074^{* * *}$ & .012 \\
& $(.005)$ & $(.005)$ & $(.005)$ & $(.005)$ & $(.012)$ & $(.008)$ \\
\cline { 2 - 7 } Fixed effects: & & & & & & \\
Firm fixed-effects & Yes & Yes & Yes & Yes & Yes & Yes \\
Year dummies & No & Yes & No & Yes & Yes & Yes \\
Year $\times$ sector dummies & No & No & Yes & No & No & No \\
\cline { 2 - 7 } Observations & $1,447,299$ & $1,447,299$ & $1,447,299$ & $1,177,846$ & 315,768 & 410,210 \\
Adjusted $R^{2}$ & .16 & .16 & .16 & .15 & .13 & .20 \\
\hline \hline
\end{tabular}

Notes: $* * *$ pvalue $<0.01, * *$ pvalue $<0.05, *$ pvalue $<0.10$.

Robust standard errors in brackets.

Notes: The dependent variable is capital expenditure net of real estate acquisition normalized by the $P P E$ stock in year $t-1$. Column 1 is an OLS estimation of equation (19), where $N R E H_{i t-1}^{d}$ is replaced by $R E v a l u e_{i t-1}^{d}$, without year dummies. Column 2 corresponds to the same equation with year dummies. Column 3 introduces also year $\times$ sector dummies. Column 4 reports the estimates for single-establishment firms. Columns 5 and 6 present the same estimates for "small" and "large" firms, respectively. Sources: FiBEn.

from the profit channel. Following the identification strategy of $C S T$, we can estimate this parameter by replacing $N R E H_{i t-1}^{d}$ by $R E v a l u e_{i t-1}^{d}$ in equation (19) where $R E v a l u e_{i t-1}^{d}$ is the value of real estate holdings held by firm $i$ at the end of year $t-1$, normalized by the PPE stock in period $t-1$. The results are reported in Table 9. The estimates of the parameter associated with $R E$ value indicate that firms invest 0.065 euro out of each 1 euro of real estate collateral; this result is very similar to the one obtained by CST who found a baseline parameter value of 0.06 studying US firms over the period 1993-2007. We also notice that, in these regressions, the effect of local real estate price on productive investment is unstable across sub-samples.

Another legitimate question relates to the magnitude of the negative effect associated with an increase in real estate prices for firms that hold few or no real estate asset. The estimates presented in Table 4 suggest that the median firm located in the first decile in the NREH distribution lowers its investment level by $1.8 \%$ following a $10 \%$ increase in real estate prices. For acquiring firms with no prior real estate holdings, we find a parameter value suggesting a $4.7 \%$ decrease in investment for the same increase in real estate prices. We propose to analyse these figures using an oversimplify static model where the Entrepreneur uses a Cobb-Douglas decreasing returns-to-scale technology that uses real estate assets, productive assets and labor as inputs. The elasticity of productive assets used in the production process with respect to real estate prices is given by $\xi=\frac{\iota}{\nu+\iota-1}$; where $\iota$ is the elasticity of output to real estate assets and $\nu$ is the sum of the elasticity of output 
to productive assets and the elasticity of output to labor. If we retain the hypothesis that $\nu$ worths 0.8 , which is a plausible value for the sum of the elasticity of output to productive assets and the elasticity of output to labor, then $\xi$ is equal -0.18 when $\iota$ worths 0.03 which happens to be the calibrated value of this parameter in Iacoviello (2005). ${ }^{28}$ The parameter $\xi$ reaches -0.47 if $\iota$ worths 0.064 ; which is still a plausible value for $\iota$ if we consider the average ratio of corporate real estate holding over annual output between 1993 and 2013. ${ }^{29}$ Even if this simple framework does not properly consider the law of motion of capital, it allows to show that the magnitude of the negative effects of real estate prices on investment that we find is in line with what we could expect given the share of real estate expenditure in firms' output.

\subsection{Discussion on aggregate effects of real estate prices}

It is widely known that real estate assets can be used to enhance corporate financing. This generates a channel through which real estate prices affect corporate investment. We have shown that real estate prices might also affect investment through a profit channel. These collateral and profit channels pull investment in opposite directions. Using our simple theoretical model, we have shown that the dominant channel depends on the structure of the firms' assets. Our empirical findings support this theoretical prediction. We find that a rise in real estate prices negatively affects the investment of firms holding few real estate assets in comparison to their sectoral peers, while a similar rise has a significant positive impact on the investment of firms reporting more real estate assets than their sectoral peers. We have highlighted that the reaction of employment to changes in real estate prices present a similar pattern as that of investment. These heterogeneous effects of real estate prices may distort the allocation of investment and employment growth across firms and affect aggregate investment, aggregate production and aggregate TFP. To tackle these questions, we first provide a further analysis of the firms' characteristics in each decile and we then proceed to a quick quantification exercise.

The median age of firms steadily increases with the level of real estate holdings. The age of the median non-real estate-holding firm is 13 years while the median firm that reports the highest level of real estate holdings is 28-year old (see Table 10). There is an inverted Ushaped relationship between the size of the firm (measured as the size of the balance sheet) and the intensity of real estate holdings. For real estate-holding firms, we observe a decreasing relationship between profitability (measured as the EBIT $^{30}$ margin) and the position in the NREH distribution. However, the median profitability of no real estate firms is below the median profitability of the whole sample. The relationship between TFP and the position in the NREH distribution presents similar patterns. Interestingly enough, the median TFP is lower in the two top deciles of the $N R E H$ distribution, precisely the ones for which we find a sizable positive effect of real estate prices on investment.

Hence, firms which are the most likely to take advantage of an increase in real estate prices tend to be older, less profitable and characterized by a lower TFP than the median firm. ${ }^{31}$ Our results reveal a plausible link between real estate prices and aggregate TFP

\footnotetext{
${ }^{28}$ The paper is calibrated using US data.

${ }^{29}$ In our sample, the ratio of the total market value of corporate real estate holding over total annual value-added is, in average over the 20 years, equal to 2.17 . In the national account produced by the INSEE, this average ratio is 2.07 .

${ }^{30}$ Earning Before Interest and Tax.

${ }^{31}$ Consequently, an increase in real estate prices tends to give competitive advantage to those firms over
} 
Table 10: Descriptive statistics per NREH decile

\begin{tabular}{lcccc}
\hline & Med. age & Med. size of BS & Med. EBIT marg. & Med. TFP \\
\hline No real estate & 13 & 0.9 & .051 & 4.72 \\
Decile 1 & 13 & 1.5 & .060 & 4.81 \\
Decile 2 & 14 & 1.4 & .058 & 4.80 \\
Decile 3 & 15 & 1.5 & .058 & 4.81 \\
Decile 4 & 16 & 1.6 & .059 & 4.82 \\
Decile 5 & 17 & 1.6 & .059 & 4.82 \\
Decile 6 & 18 & 1.7 & .059 & 4.82 \\
Decile 7 & 20 & 1.7 & .057 & 4.81 \\
Decile 8 & 22 & 1.6 & .055 & 4.80 \\
Decile 9 & 24 & 1.6 & .051 & 4.78 \\
Decile 10 & 28 & 1.4 & .043 & 4.72 \\
\hline Overall & 16 & 1.1 & .053 & 4.75 \\
\hline \hline
\end{tabular}

Notes: The median age is expressed in year and the median size of the balance sheet in million euros. The EBIT margin is the ratio of the Earning Before Interest and Tax on Sales. The TFP is estimated separately for each 2- digit sector using the method proposed byLevinsohn and Petrin (2003). Sources: FiBEn.

growth. If real estate prices foster investment in firms exhibiting low TFP, a rise in real estate prices increases the share of these firms in the economy, putting a drag on TFP growth through a negative reallocation of inputs across heterogeneous firms. In a recent contribution, Cecchetti and Kharroubi (2015) highlight a mechanism relating asset pledgeability to productivity growth in order to explain a negative correlation between the financial sector expansion and the aggregate productivity growth (Cecchetti and Kharroubi, 2012).

One may also be interested in quantifying the impact of an exogenous increase in real estate on aggregate investment, aggregate production and aggregate TFP from our estimated parameters. This exercise, based on reduced form estimates, is performed to give a sense of the magnitude of the economic effects and is not intended to constitute a precise evaluation.

The impact of an exogenous shock on prices, affecting all firms, on aggregate investment can be obtained by summing the individual impacts across firms. Let's denote $I$ the aggregate investment, with $I=\sum_{i} i_{i, j}$ where $i_{i, j}$ is the investment of the firm $i$ pertaining to the $j$ th decile in the $N R E H$ distributions. We hence have $\frac{\partial I}{\partial l \text { Price }}=\sum_{i} \frac{\partial i_{i, j}}{\partial l \text { Price }}=\sum_{i} \beta_{2}^{j} k_{i, j}$ where $\beta_{2}^{j}$ are the estimated coefficients associated with real estate prices in equation (20), reported in the column 2 in Table 4, for firm pertaining to the $j$ th decile in the NREH distribution and $k_{i, j}$ is the PPE stock of firms $i$. Normalizing by $I$, we obtain the elasticity of aggregate investment to real-prices prices. From our data, we obtain an elasticity of .14;

the others. In addition, we cannot reject the assumption that corporate loans granted as a result of an increasing collateral value have crowded out loans available for firms owning less collateral. This could be a plausible complementary explanation for our empirical results. Such a mechanism relates to the recent findings of Chakraborty, Goldstein, and MacKinlay (2014) that booming housing prices in the US have led banks to reduce commercial lending because of a crowding-out effect resulting from lending opportunities in the residential housing market. 
meaning that a $10 \%$ increase in real estate prices entails a jump by $1.4 \%$ in investment. This translates into a short term elasticity of aggregate capital to real estate prices of $.056 .{ }^{32}$

We now turn to the impact of price shocks on aggregate production. For the sake of simplicity, we consider a Cobb-Douglas technology that only uses fixed assets and labor as inputs, that is to say $y_{i, j, s}=\theta_{i, j, s} k_{i, j, s}^{\alpha_{s}} l_{i, j, s}^{\beta_{s}}$, where the indices $i, j, s$ indicate the firm $i$, operating in sector $s$, pertaining to the $j$ th decile in the $N R E H$ distributions. The parameters of the production function are estimated separately for each 2-digit sector. We denote $Y$ the aggregate production and $Y=\sum_{i} y_{i, j, s}$. The aggregate effect of prices on production can be recover by summing the impact across firms. It can be shown that $\frac{\partial Y}{\partial l \text { Price }}=\sum_{i}\left(\alpha_{s} \frac{\partial k_{i, j, s} / k_{i, j, s}}{\partial l \text { Price }}+\beta_{s} \frac{\partial l_{i, j, s} / l_{i, j, s}}{\partial l \text { Price }}\right) y_{i, j, s}=\sum_{i}\left(\alpha_{s} \beta_{2, i n v}^{j}+\beta_{s} \beta_{2, \text { emp }}^{j}\right) y_{i, j, s}$ where $\beta_{2, i n v}^{j}$ and $\beta_{2, e m p}^{j}$ are the estimated coefficients associated with real estate prices, respectively reported in the column 2 in Table 4 and in the column 3 of Table 8, for firm pertaining to the $j$ th decile in the NREH distribution. Normalizing by $Y$, we find an elasticity of aggregate production to real estate prices equal to .003. This very low elasticity results from the employment contraction following a price increase for a large share of firms. ${ }^{33}$ The negative impact of real estate prices on aggregate employment, along with a positive impact on aggregate investment, cannot easily be accounted for by a model without labor and housing markets because, in a simple optimal investment model, the link between real estate prices and employment can only be channeled through the complementarities between fixed capital and labor. Housing prices and wages being intertwined, an increase in real estate prices is likely to be associated with an increase in labor costs that has a direct negative effect on labor demand. Precisely assessing the magnitude of this direct effect is beyond the scope of this paper.

Finally, we compute the effect of a price increase on aggregate TFP. As mentioned above, because of its interaction with the credit friction, a price increase may affect allocation of inputs across firms in a way that damage aggregate productivity. Lets define the shareweighted aggregate TFP as $\Theta=\sum_{i} \frac{y_{i, j, s}}{Y} \theta_{i, j, s}$. We have $\frac{\partial \Theta}{\partial l \text { Price }}=\sum_{i} \frac{1}{Y^{2}} \theta_{i, j, s}\left(\frac{\partial y_{i, j, s}}{\partial l P r i c e} Y-\right.$ $\left.\frac{\partial Y}{\partial l P r i c e} y_{i, j, s}\right)$ and we can compute $\frac{\partial \Theta}{\partial l P r i c e}$ with our estimates and our database. We find an elasticity equal to -.004 .

Those calculation doesn't take into account the effect of prices on business creation. A related literature has highlighted that real estate prices may affect small business creations and self-employment. Adelino, Schoar, and Severino (2015) find that the increase in real estate prices has enhanced growth in employment by easing small business starts in the US between 2002 and 2007. Schmalz, Sraer, and Thesmar (2013) combine local house prices with micro-level data on home ownership by entrepreneurs. They find that the differences in the size of businesses created by homeowners and renters and the propensity to start a business are larger in regions where house prices have significantly increased. We do not address this question in this study even though such mechanisms could also be important.

\section{Conclusion}

The present paper has investigated the effect of real estate prices on productive investment through a theoretical framework and an empirical validation on a large French firm-level

\footnotetext{
${ }^{32}$ Computations are made with sample made of all real estate holding firms over the whole period.

${ }^{33}$ Computing the elasticity of aggregate employment to real estate prices, as we do for investment, we obtain a value of -.009 .
} 
database.

Our theoretical framework models firms' investment with credit rationing and real estate assets which can be used as collateral but also as inputs in the production process. Real estate prices operate through two channels with opposite effects on borrowing capacities of credit-constrained firms. Through the first channel, an increase in real estate prices raises the market value of firms' pledgeable assets and facilitates their access to credit. Through the second channel, this increase raises the cost of structures, decreasing expected profit and damaging borrowing capacities. As a result, the impact of an increase in real estate prices on credit-constrained firms depends on firms' characteristics, the level of real estate holdings being the main determinant.

Our empirical analysis has validated our main theoretical predictions. The impact of real estate prices on productive investment is globally positive, although modest and weakly robust. Considering firms' heterogeneity, we do find a negative impact for firms in the lower part of the sectoral distribution of real estate ownership, and a positive impact in the upper part. These results suggest that French firms have faced binding borrowing constraints over the studied period.

Hence, real estate price fluctuations affect resources allocation. Real estate price hikes tend to favor older and, in average, less productive firms and may have weighed on firms' overall performance and on the creative destruction process in the bubble years. Future research could hence focus on the impact of real estate changes on productivity dynamics, specifically through entry/exit processes. 


\section{References}

[1] M. Adelino, A. Schoar, and F. Severino. "House prices, collateral, and self-employment". In: Journal of Financial Economics 117.2 (2015), pp. 288-306 (cit. on p. 31).

[2] H. Almeida, M. Campello, and M. Weisbach. "The cash flow sensitivity of cash". In: The Journal of Finance 59.4 (2004), pp. 1777-1804 (cit. on p. 10).

[3] P. Askenazy. "Capital Prices and Eurozone Competitiveness Differentials". IZA Discussion Paper, No 7219. 2013 (cit. on p. 1).

[4] T. Beck, A. Demirgüç-Kunt, and M.S. Martinez Peria. "Bank financing for SMEs around the world: Drivers, obstacles, business models, and lending practices". World Bank Policy Research Working Paper Series. 2008 (cit. on p. 1).

[5] A. Berger and G. Udell. "Collateral, loan quality and bank risk". In: Journal of Monetary Economics 25.1 (1990), pp. 21-42 (cit. on p. 1).

[6] K. Case, J. Quigley, and R. Shiller. "Comparing wealth effects: the stock market versus the housing market". In: Advances in macroeconomics 5.1 (2005) (cit. on p. 2).

[7] S. Cecchetti and E. Kharroubi. "Reassessing the impact of finance on growth". BIS Working Paper. 2012 (cit. on p. 30).

[8] S. Cecchetti and E. Kharroubi. "Why does financial sector growth crowd out real economic growth?" BIS Working Paper. 2015 (cit. on p. 30).

[9] G. Cette, S. Corde, and R. Lecat. "'Rupture de tendance de la productivité en France : quel impact de la crise ?"”. mimeo. 2017 (cit. on p. 2).

[10] G. Cette, J. Fernald, and B. Mojon. "The pre-Great Recession slowdown in productivity". In: European Economic Review 88 (2016), pp. 3-20 (cit. on p. 1).

[11] I. Chakraborty, I. Goldstein, and A. MacKinlay. "Do asset price bubbles have negative real effects?" Mimeo, Wharton School, University of Pennsylvania. 2014 (cit. on p. 30).

[12] T. Chaney, D. Sraer, and D. Thesmar. "The Collateral Channel: How Real Estate Shocks Affect Corporate Investment”. HEC Working Paper. 2009 (cit. on p. 3). 
[13] T. Chaney, D. Sraer, and D. Thesmar. "The Collateral Channel: How Real Estate Shocks Affect Corporate Investment". In: The American Economic Review 102 (2012), pp. 2381-2409 (cit. on p. 1).

[14] T. Chaney, D. Sraer, and D. Thesmar. "Real Estate Collateral and Labor Demand". Mimeo, Toulouse School of Economics. 2013 (cit. on pp. 2, 11, 12).

[15] P.P. Combes and L. Gobillon. "The empirics of agglomeration economies". Mimeo, Sciences Po. 2014 (cit. on p. 4).

[16] G. Favara and J. Imbs. "Credit supply and the price of housing". In: The American Economic Review 105.3 (2015), pp. 958-992 (cit. on p. 2).

[17] D. Fougère and M. Poulhes. "The Effect of Housing on Portfolio Choice: A Reappraisal Using French Data". In: CEPR Discussion Paper No. 9213 (2012) (cit. on pp. 9, 38).

[18] J. Friggit. "Le prix des logements sur longue période". In: Informations sociales 155.5 (2009), pp. 26-33 (cit. on pp. 9, 38).

[19] J. Gan. "Collateral, debt capacity, and corporate investment: Evidence from a natural experiment". In: Journal of Financial Economics 85.3 (2007), pp. 709-734 (cit. on p. 1).

[20] O. Hart and J. Moore. "Property Rights and the Nature of the Firm". In: Journal of political economy (1990), pp. 1119-1158 (cit. on p. 2).

[21] M. Iacoviello. "House Prices, Borrowing Constraints, and Monetary Policy in the Business Cycle". In: American Economic Review 95.3 (2005), pp. 739-764 (cit. on p. 29).

[22] L. Kaas, P. Pintus, and S. Ray. "Land collateral and labor market dynamics in France". In: European Economic Review (2014) (cit. on p. 1).

[23] S. Kaplan and L. Zingales. "Do investment-cash flow sensitivities provide useful measures of financing constraints?" In: The Quarterly Journal of Economics (1997), pp. 169-215 (cit. on p. 10).

[24] N. Kiyotaki and J. Moore. "Credit Cycles". In: Journal of Political Economy 105 (1997), pp. 211-248 (cit. on p. 1). 
[25] J. Levinsohn and A. Petrin. "Estimating production functions using inputs to control for unobservables". In: The Review of Economic Studies 70.2 (2003), pp. 317-341 (cit. on pp. 10, 11, 15, 30).

[26] Z. Liu, P. Wang, and T. Zha. "Land-Price Dynamics and Macroeconomic Fluctuations". In: Econometrica 81.3 (2013), pp. 1147-1184 (cit. on p. 1).

[27] N. Mora. "The effect of bank credit on asset prices: evidence from the Japanese real estate boom during the 1980s". In: Journal of Money, Credit and Banking 40.1 (2008), pp. $57-87$ (cit. on p. 2).

[28] M. Schmalz, D. Sraer, and D. Thesmar. "Housing collateral and entrepreneurship". National Bureau of Economic Research No. 19680. 2013 (cit. on p. 31).

[29] J. Tirole. The theory of corporate finance. Princeton University Press, 2010 (cit. on pp. 2-4).

[30] J. Wu, J. Gyourko, and Y. Deng. "Real estate collateral value and investment: The case of China". In: Journal of Urban Economics 86 (2015), pp. 43-53 (cit. on p. 2). 


\section{Appendix}

\subsection{Appendix A: Proof of proposition 1}

We know that $i^{*}$ and $R^{*}$ maximize the objective function. Let's the function $V(i, R)$ denote the value of the objective function associated with an investment $i$ and a number of real estate units $R$. By definition, $\forall(g, h) \in \mathbb{R}^{2}, V\left(i^{*}+g, R^{*}+h\right)-V\left(i^{*}, R^{*}\right) \leq 0$. A second-order Taylor approximation of the function $V$ around $\left(i^{*}, R^{*}\right)$ gives:

$$
\begin{aligned}
V\left(i^{*}+g, R^{*}+h\right)-V\left(i^{*}, R^{*}\right) \approx & \frac{y_{k k}\left(k^{*}, R^{*}, \theta\right)}{1+r} g^{2} \\
& +2 \frac{y_{k R}\left(k^{*}, R^{*}, \theta\right)}{1+r} g h+\frac{y_{R R}\left(k^{*}, R^{*}, \theta\right)}{1+R} h^{2}
\end{aligned}
$$

Dividing by $h^{2}$ we have:

$$
\begin{aligned}
\frac{V\left(i^{*}+g, R^{*}+h\right)-V\left(i^{*}, R^{*}\right)}{h^{2} \approx} & \frac{y_{k k}\left(k^{*}, R^{*}, \theta\right)}{1+r} \frac{g^{2}}{h^{2}} \\
& +2 \frac{y_{k R}\left(k^{*}, R^{*}, \theta\right)}{1+r} \frac{g}{h}+\frac{y_{R R}\left(k^{*}, R^{*}, \theta\right)}{1+R}
\end{aligned}
$$

We know that, $\forall g \in \mathbb{R}, \forall h \in \mathbb{R}^{*}$ :

$$
\frac{V\left(i^{*}+g, R^{*}+h\right)-V\left(i^{*}, R^{*}\right)}{h^{2}}<0
$$

Hence we can write:

$$
\left(2 \frac{y_{k R}\left(k^{*}, R^{*}, \theta\right)}{1+r}\right)^{2}-4 \frac{y_{k k}\left(k^{*}, R^{*}, \theta\right)}{1+r} \frac{y_{R R}\left(k^{*}, R^{*}, \theta\right)}{1+r}<0
$$

and eventually:

$$
\frac{y_{k R}\left(k^{*}, R^{*}, \theta\right)^{2}}{y_{R R}\left(k^{*}, R^{*}, \theta\right)}-y_{k k}\left(k^{*}, R^{*}, \theta\right)>0
$$

\subsection{Appendix B: Proof of proposition 2}

Let $F$ be a function of $i$, with $i \in\left[0, i^{*}\right]$ such that:

$$
F(i)=(1+r)+\frac{L-S+p R_{0}}{L}\left(y\left(k_{0}+i, R, \theta\right)-r p\left(R-R_{0}\right)\right)-(1+r) i-(1+r) B_{0}
$$

We get:

$$
\frac{\partial F}{\partial i}(i)=\frac{L-S+p R_{0}}{L} y_{k}\left(k_{0}+i, R, \theta\right)-(1+r)
$$

And:

$$
\frac{\partial^{2} F}{\partial i \partial i}(i)=\frac{L-S+p R_{0}}{L} y_{k k}\left(k_{0}+i, R, \theta\right)
$$


From the properties of the function $y$ we deduce that; $\forall i \in\left[0, i^{*}\right], \frac{\partial^{2} F(i)}{\partial i \partial i}<0$. We know that, in the constrained case, $\frac{L-S+p R_{0}}{L} \in[0,1]$. From the first equation in system (6), we know that $\frac{\partial F}{\partial i}\left(i^{*}\right)<0$.

We distinguish two cases:

- If $\frac{\partial F}{\partial i}(0)<0$, we conclude that, $\forall i \in\left[0, i^{*}\right]$ :

$$
(1+r)-\frac{L-S+p R_{0}}{L} y_{k}\left(k_{0}+i, R, \theta\right)>0
$$

- If $\frac{\partial F}{\partial i}(0) \geq 0$, we know that there exists a unique threshold $\tilde{i} \in\left[0, i^{*}\right)$ such that $\frac{\partial F}{\partial i}(i)<0$ if and only if $i>\tilde{i}$. The function $F$ is increasing on the interval $[0, \tilde{i}]$ and decreasing on the interval $\left[\tilde{i}, i^{*}\right]$. The constraint on the initial amount of debt, i.e., $\frac{L-S+p R_{0}}{L}\left(y\left(k_{0}, R, \theta\right)-c_{r e}(R)\right) \geq(1+r) B_{0}$, insures that $F(0)>0$ and we deduce from the variation of $F$ that the value $i$ satisfying $F(i)=0$ pertains to the interval $\left(\tilde{i}, i^{*}\right]$. Thus, when $i$ denotes the investment in the constrained case, we also have:

$$
(1+r)-\frac{L-S+p R_{0}}{L} y_{k}\left(k_{0}+i, R, \theta\right)>0
$$

We conclude that the sign of $\frac{\partial i}{\partial p}$ is determined by the sign of $P\left(R_{0}\right)$.

The discriminant of the polynomial $P$ is strictly positive and $P(0)<0$. We know that $P$ has a unique positive real root $\bar{R}$ and we conclude that $\frac{\partial i}{\partial p} \geq 0$ if and only if $R_{0} \geq \bar{R}$, with:

$$
\bar{R}=\frac{2 p r R-y(k, R, \theta)-r(L-S)+\sqrt{[y(k, R, \theta)-2 r p R+r(L-S)]^{2}+8 r^{2} p(L-S) R}}{4 r p}
$$

Note that the relative position of $\bar{R}$ to $\frac{S}{p}$ depends on the parameters value and the functional form of $y$.

The sign of $\frac{\partial i}{\partial R_{0}}, \frac{\partial i}{\partial c_{0}}, \frac{\partial i}{\partial B_{0}}$ and $\frac{\partial i}{\partial \theta}$ can be obtained thanks to the result derived above. We have:

$$
\begin{gathered}
\frac{\partial i}{\partial R_{0}}=\frac{\frac{L-S+p R_{0}}{L} r p+\frac{p}{L}\left[y(k, R, \theta)-r p\left(R-R_{0}\right)\right]}{(1+r)-\frac{L-S+p R_{0}}{L} y_{k}(k, R, \theta)}>0 \\
\frac{\partial i}{\partial c_{0}}=\frac{1}{(1+r)-\frac{L-S+p R_{0}}{L} y_{k}(k, R, \theta)}>0 \\
\frac{\partial i}{\partial B_{0}}=\frac{-1}{(1+r)-\frac{L-S+p R_{0}}{L} y_{k}(k, R, \theta)}<0 \\
\frac{\partial i}{\partial \theta}=\frac{\frac{L-S+p R_{0}}{L} y_{\theta}(k, R, \theta)}{(1+r)-\frac{L-S+p R_{0}}{L} y_{k}(k, R, \theta)}>0
\end{gathered}
$$

\subsection{Appendix C: Further details on real estate price indices \\ 6.4 Appendix D: Further details on real estate partnerships}


Figure 2: Real estate prices at the département level: 1952-2013

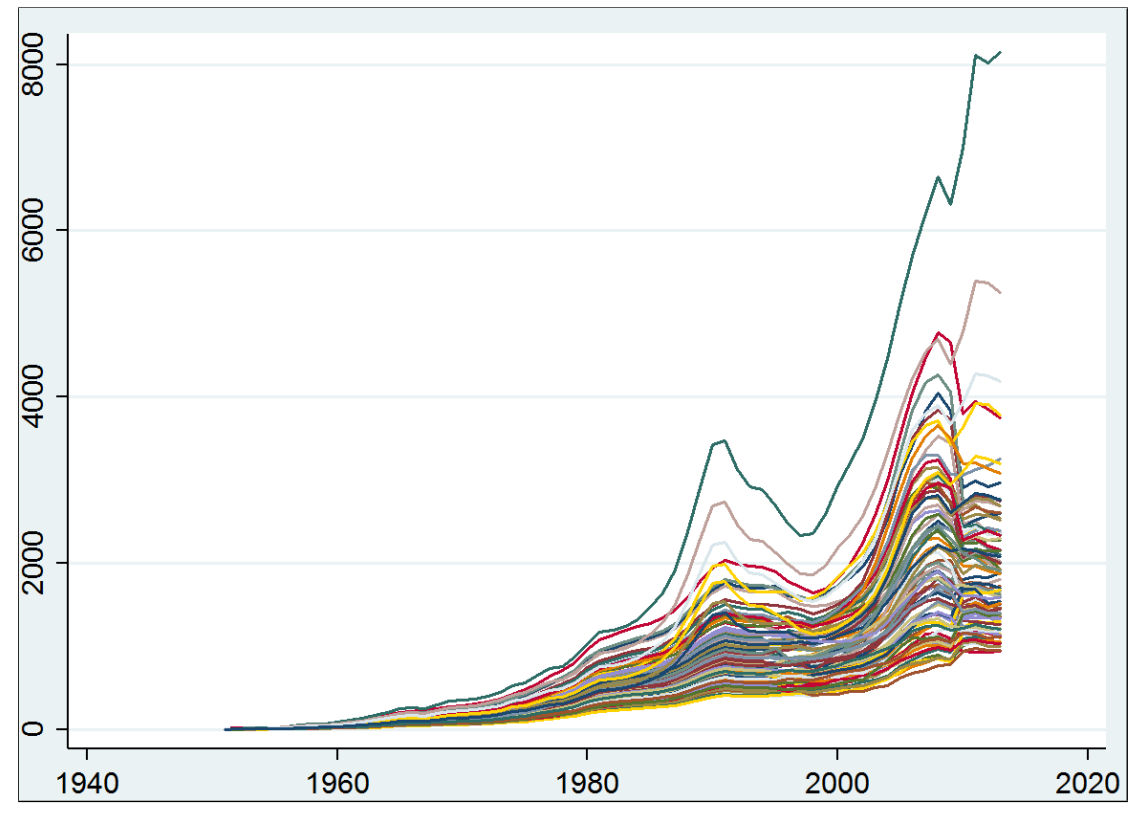

Notes:This graph plots real estate prices in euros (2013) per square meters in each mainland French département. The series are built with the Notaires-INSEE apartment price indices built by Fougère and Poulhes (2012). Sources: French Notaires, Friggit (2009). 
Figure 3: Real estate prices in France by market segment: 1998-2015

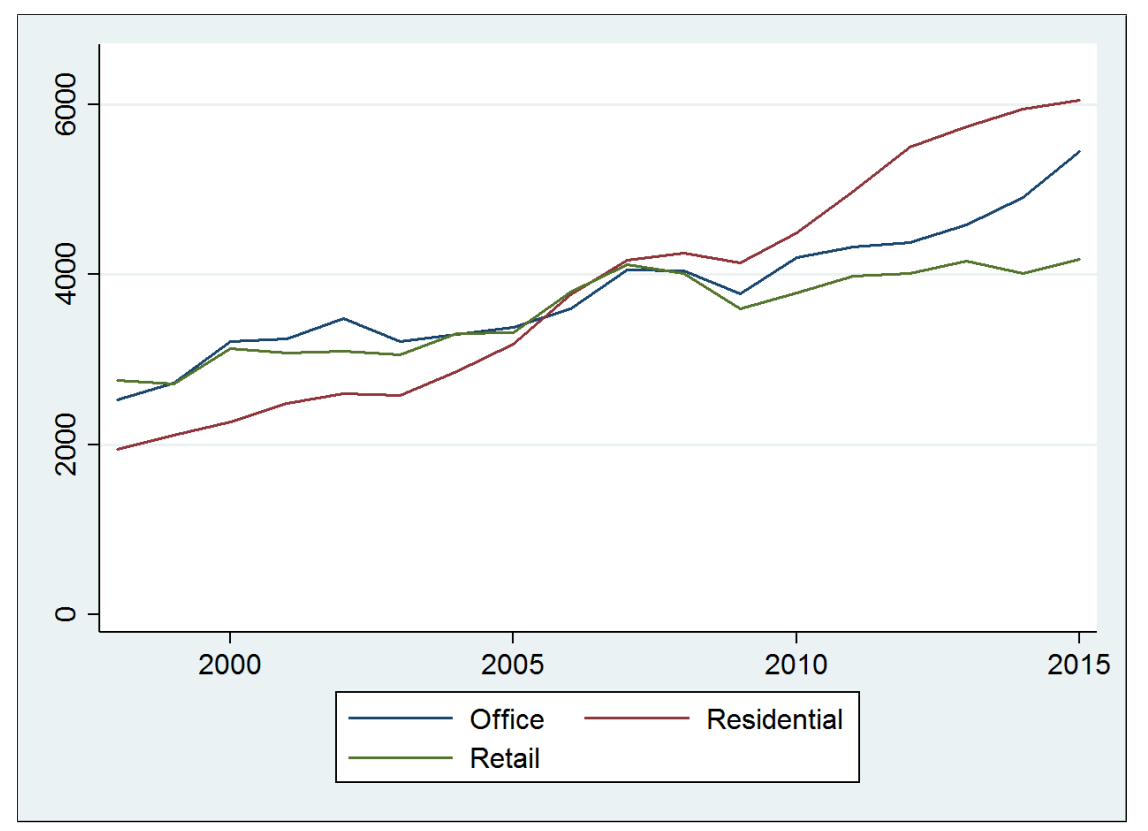

Notes: This graph plots real estate prices in euros per square meters in three market segments: Office, Residential and Retail. Sources: HCSF report (MSCI). 
Figure 4: The number of real estate partnerships (Sociétés Civiles Immobilières) incorporated in France: 1978-2013

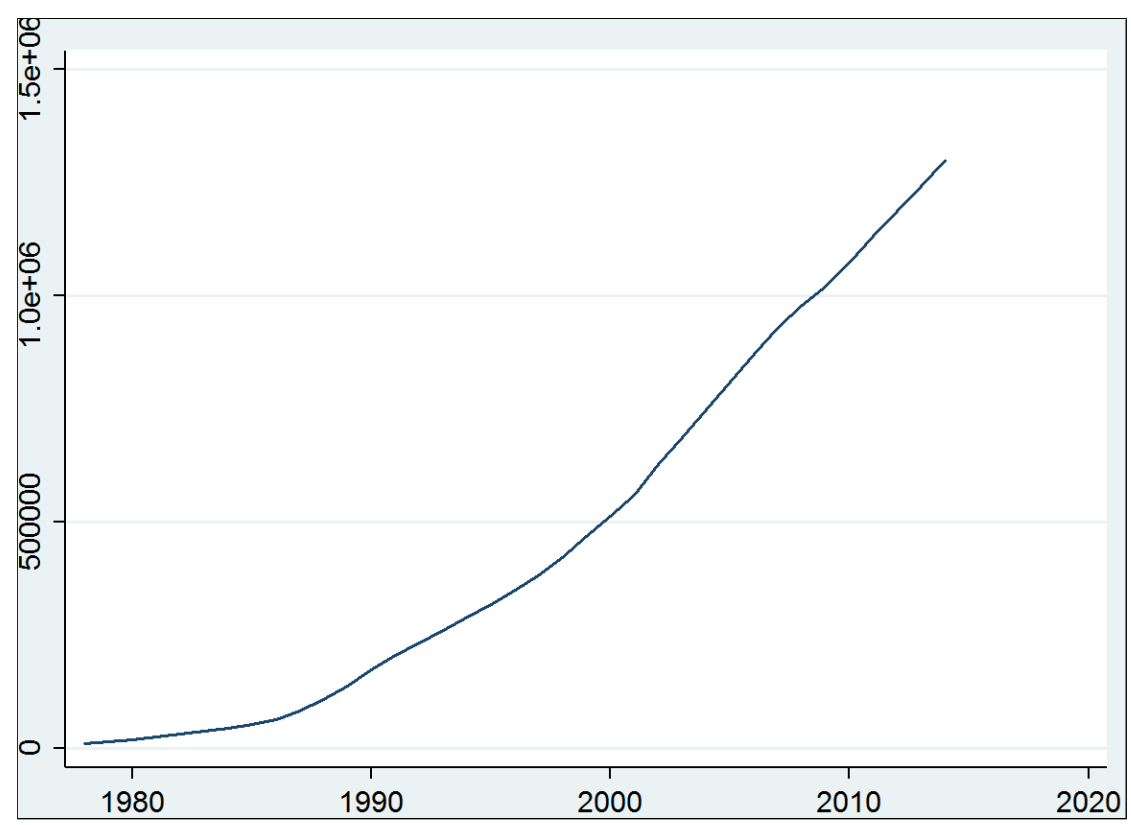

Notes: This graph plots the evolution of the number of Sociétés Civiles Immobilières incorporated in France since 1978. Source: Infogreffe. 